\title{
The potential of historical hydrology in Switzerland
}

\author{
Oliver Wetter \\ Oeschger Center for Climate Change Research (OCCR) and Institute of History, Section of Economic, Social and \\ Environmental History (WSU), University of Bern, Bern, Switzerland
}

Correspondence to: Oliver Wetter (oliver.wetter@hist.unibe.ch)

Received: 11 July 2017 - Discussion started: 4 August 2017 Accepted: 15 October 2017 - Published: 23 November 2017

\begin{abstract}
Historical hydrology is based on data derived from historical written, pictorial and epigraphic documentary sources. It lies at the interface between hydrology and environmental history, using methodologies from both disciplines basically with the goal of significantly extending the instrumental measurement period with experience from the pre-instrumental past. Recently this field of research has gained increased recognition as a tool to improve current flood risk estimations when EU guidelines regulated by law the quantitative consideration of previous floods. ${ }^{1}$ Awareness to consider pre-instrumental experience in flood risk analysis seems to have risen at the level of local and federal authorities in Switzerland as well. The 2011 Fukushima catastrophe probably fostered this rethinking process, when pressure from the media, society and politics as well as the regulations of the International Atomic Energy Agency (IAEA) forced the authorities to reassess the current flood risk analysis for Swiss nuclear power plants. In 2015 a historical hydrological study was commissioned by the Federal Office for the Environment (FOEN) to assess the magnitudes of preinstrumental Aare River flood discharges, including the most important tributaries (the Saane, Emme, Reuss and Limmat rivers). The results of the historical hydrological study serve now as the basis for the main study, EXAR (commissioned under the lead of FOEN in cooperation with the Swiss Nuclear Safety Inspectorate (ENSI), the Swiss Federal Office of Energy (SFOE), the Federal Office for Civil Protection (FOCP), and the Federal Office of Meteorology and Climatology (MeteoSwiss)), which combines historical and climatological analysis with statistical approaches and mathemati-
\end{abstract}

\footnotetext{
${ }^{1}$ Guideline 2007/60/EG of the European Parliament and Council from 23 October 2007 on assessment and management of flood risks, Official Journal of the European Union, L 288, 27-34, Brussels, 2007.
}

cal models with the goal of better understanding the hazards and possible interactions that can be caused by extreme flood events. In a second phase the catchment of the River Rhine will be targeted as well. More recently several local historical hydrological studies of smaller catchments have been requested by the responsible local authorities. The course for further publicly requested historical hydrological analysis seems thus to have been set. This paper therefore intends to discuss the potential of historical hydrological analysis, with a focus on the specific situation in Switzerland.

\section{Introduction}

This paper aims to describe the potential of historical hydrology in Switzerland in terms of data availability, methodologies, reconstruction capabilities and usefulness for the scientific and practical communities like federal or cantonal agencies and private engineering companies by adding a longerterm historical perspective to the spectrum of already existing risk and vulnerability assessments. The concept of historical hydrology is - not by its definition but by its specific application - quite often used as an equivalent to analysis of - mostly - extreme pre-instrumental or early instrumental flood events even though the research interest of historical climatology is more heterogeneous. The analysis of the vulnerability of past societies to extreme hydrological events (e.g. Pfister, 2011) can be seen as the most "classical" historical approach in the field of historical hydrology, whereas the reconstruction of anthropogenic influence on runoff conditions due to flood protection and river regulation constructions (Vischer, 2003; Salvisberg, 2017; Longoni, 2017; Longoni and Wetter, 2017; Bolzern, 2018) sheds light on hydrological and hydraulic research questions. The reconstruction 
of temporal and spatial patterns of floods (e.g. Glaser et al., 2010), or the analysis of meteorological triggers of particular flood events (e.g. Mudelsee et al., 2004), however, do have a more climatological research focus. In this paper the almost complete spectrum of historical hydrology shall be applied, meaning that all kinds of pre-instrumental hydrological events like floods or droughts as well as precedent meteorological causes of such events or the anthropogenic influence on discharge conditions are meant when the term "historical hydrology" is used. The focus will be primarily laid on obtaining quantitative hydrological and meteorological information from all kinds of documentary sources (written, pictorial, epigraphic), with the goal - whenever possible - of analysing pre-instrumental historical hydrological events holistically in the sense of the definition of historical hydrology. Solely the society and vulnerability aspect does not stay in the forefront of interest in this paper unless anthropogenic interventions significantly influenced the hydrological system. The specific targets are (1) to describe the strengths and weaknesses of the available historical hydrological documentary evidence, (2) to shed light on the existing basic methodologies leading to long-term frequency, seasonality and magnitude reconstructions of pre-instrumental hydrological events, (3) to discuss the comparability of reconstructed pre-instrumental flood events compared to current events and (4) to provide an outlook for future analysis which (in some cases) might be unique to Switzerland.

\section{Data}

The general historical documentary data availability in Switzerland is good for several reasons. First it has to be mentioned that Switzerland has not been involved in war activities anymore after the Sonderbund War in 1847 (a very short-term civil war causing approximately 150 casualties and around 400 wounded; Remark, 1997), which could have led to significant losses of archives and historical documents. Confederate troops from the Old Swiss Confederacy ( $\sim 13$ th century to 1798) gained an aura of invincibility because of their tactics and combat strength in open field battles, at the latest after they devastatingly defeated the Burgundian forces three times in a row during the Burgundian Wars (14741477), which - with their outstanding artillery and heavy cavalry - was a military superpower at that time (Lehmann, 1995). Confederate troops on the other hand lacked adequate besieging technologies and tactics to successfully take over bastioned cities. This fact might be the reason why, generally speaking, Swiss cities (and thus archives) were not too negatively affected during Old Swiss Confederacy war activities: because the battles were fought in open fields, either besieging was not successful most of the time or cities surrendered peacefully. When Napoleonic military forces invaded Swiss territory, resulting in the Helvetic Republic (1798-1803) and the Mediation period (1803-1813), au- thorities from important Old Swiss Confederate powers like Basel, Freiburg, Bern, Solothurn, Schaffhausen and Zürich either resigned or peacefully accepted the handover of power (Christian, 1998). Again, Swiss archives and thus important historical documents were thus luckily not destroyed during the Napoleonic-influenced era. This unfortunately is not true for most of the bridges, which were systematically destroyed by French forces on their retreat. This military tactic not only complicated the advance of the opposing forces, but also significantly aggravates the reconstruction of many pre-instrumental flood events, because documentary pre-instrumental flood evidence in many cases is either directly or indirectly related to these infrastructures, which at certain locations survived ice drifts and floods for several centuries before they were destroyed by the French. The second reason why the historical documentary data availability is good in Switzerland can be attributed to the lack of major large-scale natural disasters that compromised important cities (and thus also archives) since the great and destructive earthquake of 1356 that almost completely destroyed the city of Basel. The destruction of Basel was not caused so much by the seismic shocks as more importantly by the outbreak of fire. After a foreshock that took place in the late afternoon, most of the citizens fled to open fields, leaving the many fireplaces unguarded, which then were destroyed during the main seismic shocks, causing an unprecedented town fire that lasted, according to the chronicles, 8 days until the fire was extinguished because there was nothing left that could continue to nurture the flames (Meyer, 2006). Speaking of town fires, it has to be stated that the third reason why the historical documentary data availability is good in Switzerland is several related facts that taken together significantly lower the vulnerability towards town fires as well as towards other "natural" disasters. The beginning of the petrification process, especially of important buildings, started quite early in Swiss towns and can, e.g. for Basel, be assigned to the 12th century, which is more or less true also for other major Swiss cities (D'Aujourd'hui and Lavicka, 1982). Important and powerful people, groups and institutions were among the first who built expensive and representative buildings in stone. The same political, religious and economically influential circles produced the vast majority of historical documents which were archived in those comparably (for wooden buildings) fire-safe buildings. The inventories of the state archive of Basel include a huge variety of archival materials (produced by the nobility, the church, guilds, city authorities and important institutions) that pre-date the earthquake of 1356, which demonstrates that these historical documents survived the destructive town fire caused by the quake. Cities in normal, non-cumulative disaster situations or during war activities generally had the necessary organisational skills, staff and financial and technical background to support effective measures against natural disasters (Fouquet, 1999), so that, as a rule, disasters such as town fires could be limited to a house, a street or a quarter but generally did not 
burn down the settlement as a whole, which in those cases certainly anyhow may have led to significant historical documentary losses, but at the same time they could not destroy the majority of the rest of the documents. To sum up, the generally good historical data availability in Swiss cities is founded on interrelated positive circumstances like the near absence of direct involvement in major war activities as well as the absence of cumulative natural disasters, the early beginning of petrification of important buildings and the existence of effective measures against non-cumulative disasters such as town fires. These positive historic factors in combination with the comparably recent prosperity of Switzerland, allowing the maintenance of relatively cost-intensive archives, provide an excellent opportunity for historians and historical climatologists to draw on a rich legacy of historical documents for their analysis. The Euro-Climhist and WSL databases, a rich stock of relevant historical climatological and hydrological analysis in the form of qualification works (seminar, BA, MA and PhD theses) originating mostly from the University of Bern as well as some fundamental historical hydrological publications focussing on the situation in Switzerland (e.g. Lanz-Stauffer and Rommel, 1936; Nast, 2006; Pfister, 1998, 1999, 2009; Pfister et al., 2006; Röthlisberger, 1991; Schmocker-Fackel and Naef, 2010; Vischer, 2003; Wetter et al., 2011), significantly facilitate the search for data and may even deskill further historical hydrological analysis.

According to Brázdil et al. (2005), historical documentary evidence about climate and single extreme events like floods is to be differentiated - based on their manner of observation - between direct and indirect data. Direct narrative data directly describe the course of weather and climate or extreme events like floods per se, while indirect data refer to (bio)physically based phenomena associated with weather and climate such as plant and animal life-cycle events or ice and snow seasonality features. With respect to the generation of historical documentary sources, Pfister et al. (2009) differentiate between individual and institutional sources. Individual sources are shaped by the social background, motivations and preferences of their authors, and their temporal scope is limited - at least the one in which they can be considered to be contemporaries of the events they describe - to the lifetime of the observer. Institutional sources on the other hand are produced by governments or other bodies and institutions such as the church. These institutional bodies were typically not interested in describing weather and climate or single extreme events, but kept records in order to document their activities and, in doing so, indirectly recorded the previously mentioned climate-related aspects. Their administrative routines generally involved a good level of standardisation in the way records were kept, which makes them highly homogeneous over periods of time far longer than that of a single human lifespan, which is a good prerequisite for creating long-term homogeneous series of climate parameters. The following types of individual and institutional sources shall now be described in more detail, as they are crucial for historical hydrological analysis.

Annals, chronicles, memorial books or memoirs are narrative sources that may contain descriptions of weather and related phenomena like floods with varying degrees of detail, allowing the assessment of the intensity of climate parameters (e.g. temperature or precipitation) or the magnitude of weather-related extreme events (e.g. droughts or floods).

Newspapers and journals contain similar content to the narrative sources described previously, descriptions of unusual weather or weather-related extremes, often including information about causes and consequences, and may sometimes even include (early) instrumental measurements.

Pictorial sources like paintings, etchings, photographs or ex-votos may represent weather-related phenomena like droughts or floods or include specific built landscapes which - in combination with narrative sources describing such events - may be helpful for the reconstruction of flood or low water levels. Caution needs to be taken concerning the reliability, especially with pre-18th century paintings, which are often more imaginative than true to detail.

Early scientific papers and expert reports often contain valuable information about weather and weather-related extreme events and mostly also provide additional scientific information about their occurrences, causes and impacts.

Epigraphic sources like water marks, consisting of marks or comments usually chiselled into stones of bridges, gates or houses, indicate (extraordinarily) high or low river or lake water levels, and may in most cases be regarded as valid sources that usually come closest to the accuracy of instrumental measurements. However, it has to be taken into account that this source may indeed also inherit wrong information like incorrect dating or indication of false water levels, either caused by a phenomenon called the capillary effect or by a dislocation of the mark to another place due to constructional changes.

Gauge readings, early instrumental measurements, early river profiles and official hydrological records. Gauge readings and early instrumental measurements are of great value for the comparison and validation of reconstructed pre-instrumental water levels with those that have been measured in the instrumental period. Early river profiles on the other hand allow the assessment of pre-instrumental discharges if they have been proven to be representative of the situation of the pre-instrumental period. Official hydrological records often contain additional information e.g. about the stability of river profiles, local river engineering measures or sediment transport and the like.

Accounting books can clearly be classified as so-called institutional sources. They record recurrent activities that generated income or costs in money or kind. These records are usually dated and provide short and crisp information about diverse activities the respective institution was involved in. Dated wage payment for agricultural labourers for hay, grain or grape harvest, expenditures for food and drinks 
as well as wages for the craftsmen who were ordered to guard a bridge from floating debris during a flood or recurring expenditures for the gatekeepers to open the fence at the entry of a brook into a town to prevent damming caused by floating debris may be found in this kind of source.

\section{Methodologies}

\subsection{Critique of sources}

According to the great variety of documentary evidence accessible, a range of different methodologies exist to extract their inherent climatological and hydrological information. When dealing with historical sources it is an absolute prerequisite for critically evaluating their reliability and validity before further methodologies and analysis can be applied. The exercise of historical critique of sources (e.g. Arnold, 2001) in the context of historical climatological and historical hydrological purposes includes the correction of calendars from the Julian to the Gregorian calendar as well as the distinction between contemporary and non-contemporary sources. Non-contemporary sources generally need to be treated as sources of substantial lower reliability and should only be included for analysis if they provide additional and coherent information of an already known event based on contemporary sources. Municipal accounts are seen as contemporary historical sources, as they "report" almost simultaneously to the "described" event. Newspapers or early scientific expert reports also provide contemporary accounts and details. Chronicle, annal or memorial book contemporariness is somewhat more complicated to decide. Usually the contents of chronicles or annals can be differentiated between a non-contemporary part in the beginning reporting on earlier events (either based on the author's own historical research or simply on copying from earlier works) and a contemporary part at the end, where the author's own observations are reported. The contemporariness of the reported events, as a rule of thumb, can therefore be restricted more or less to the lifetime of the work's author. A further differentiation concerning the reliability should be undertaken between distant events that only were reported to and local events that were personally witnessed by the author. This is also, or even more, true for pictorial sources. If the depicted motive is noncontemporary or only known by the artist from a narrative, the reliability usually becomes, similar to many pre-18th century paintings, much more imaginative than true to detail. Art-historical evaluations therefore urgently need to be undertaken if historical hydrological analysis is to be based on such evidence.

\subsection{Methodologies to reconstruct the frequency, seasonality and magnitudes of pre-instrumental hydrological (extreme) events}

\subsubsection{Reconstruction of the frequency and seasonality of pre-instrumental flood events}

The methodology to reconstruct pre-instrumental flood events depends on the kind of historical source and the narrative description quality the reconstruction is based on. If the narrative description quality is low (usually consisting of a date and the term "flood"), the corresponding flood evidence can obviously not be used for magnitude, but rather for longterm flood frequency or flood seasonality analysis.

\subsubsection{Reconstruction of pre-instrumental flood magnitudes}

If the description quality is abundant, but still not good enough to transform the given narrative information into quantified values like peak water levels or peak discharges, the flood magnitude may be qualitatively quantified by applying an appropriate flood magnitude index. Preinstrumental flood events are most commonly classified into three, four or rather rarely even more categories. The number of category levels mainly depends on the overall informative content of the common narrative concerning the flood evidence and the analyser's discretion. The documentary flood evidence across Switzerland can be rated as very satisfactory or good. More important cities generally provide multiple municipal chronicles and newspapers covering together the last 5 to 6 centuries more or less comprehensively. Smaller municipal bodies are usually not that well covered by chronicles, but frequently possess long-term municipal accounts, council minutes, one or two local chronicles and probably some flood marks. Taken together these sources usually provide valid information about local and supra-regional flood events on the corresponding sites. According to this commonly good and regionally well-distributed documentary flood evidence, it is recommendable to apply a four-level flood index as was developed by Sturm et al. (2001), especially in the case of an overview analysis that takes into account more than only one investigation site. This four-level index categorises the narrative flood information in accordance with the following criteria: regional expansion, level of damage and losses as well as flood duration. The narrative description quality is, compared to the overall evidence in rather rare cases, adequate enough for the reconstruction of peak water levels. In major Swiss cities, sources with qualitatively dense descriptions roughly allow between 10 and 20 peak water level reconstructions, covering the past 5 or 7 centuries. In smaller municipal bodies with much less chronicle and newspaper coverage, either none or only some individual floods may be deduced from narrative sources. The development of the principal methodology to reconstruct peak 


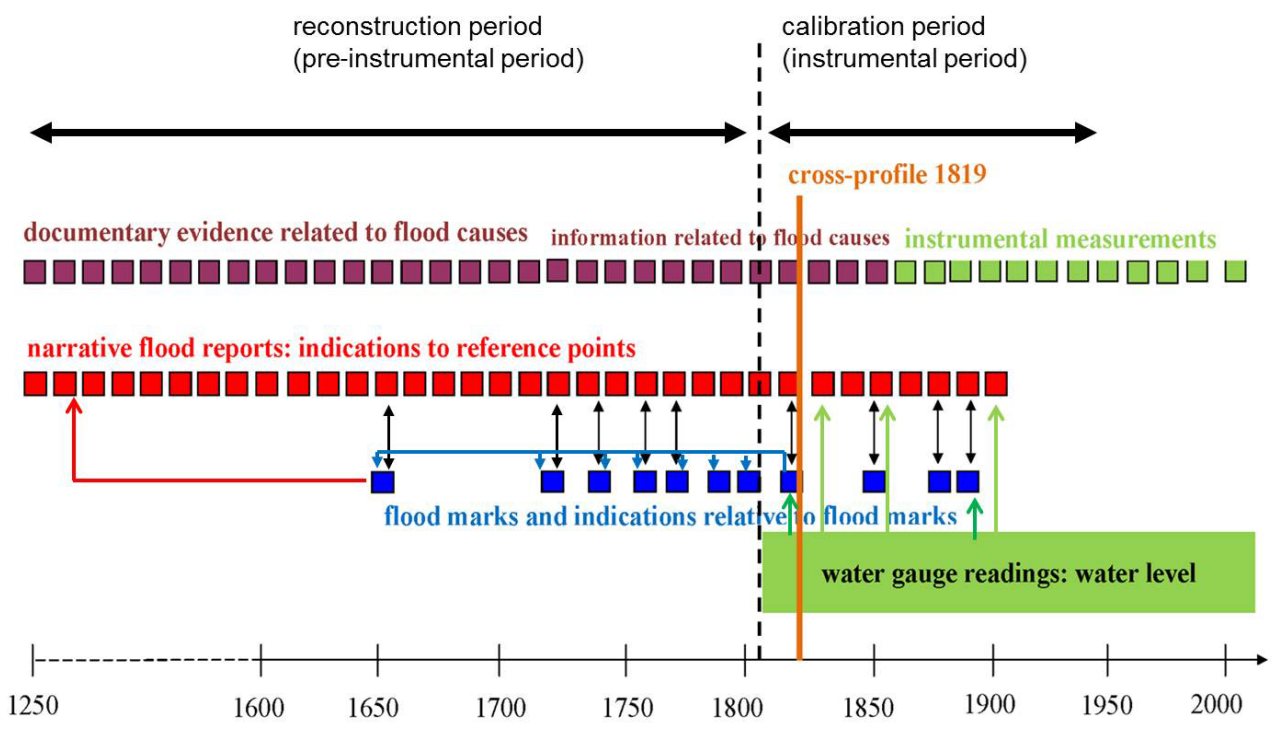

Figure 1. Qualitative calibration: assigning gauges to pre-instrumental "flood information systems" (Wetter et al., 2011).

water levels based on narrative flood evidence in Switzerland was first realised for the situation in Basel (Wetter et al., 2011). This methodology basically combines the inherent information of narrative documentary, epigraphic, pictorial and (early) instrumental flood evidence. Figure 1 demonstrates the functional principle of the qualitative calibration approach.

The vertically punctuated line represents the differentiation between the pre-instrumental and instrumental periods. In the instrumental period gauges were first determined by eye on a daily and, around the mid-19th century, on a subdaily or continuous level by instruments. Earlier societies established different "flood information systems" like affixing flood marks or describing such events as accurately and objectively as possible with the goal of intergenerational risk communication (Pfister, 2011). Many chroniclers and journalists described the magnitude of floods in the form of standard narratives, referring to specific landmarks in the built (municipal) environment. References typically were made to streets, alleys and town squares (Wetter, 2012) as well as to distinctive edifices like churches, municipal wells or other public buildings like bridges or city walls adjacent to the river. These observers generally tried to accurately describe the expansion of the flooded area as well as the depth of the inundation at specific spots in the inundated area (Wetter, 2011). If long-term gauge measurements are at hand, an overlap with narrative flood descriptions becomes likely, so that the landmarks that were narratively referred to in floods may be calibrated with the corresponding measured gauges (Fig. 1; bright green arrows). A similar calibration can be undertaken with existing flood marks (Fig. 1; dark green arrows). In the spirit of intergenerational risk commu- nication, flood marks were commonly affixed at buildings with good visibility for the public and thus were often attached at the very same building. "Gauge" identification of pre-instrumental flood marks (i.e. flood marks that are dated earlier than the start of the instrumental period) in this case is simple as they can be easily calculated from a reference flood mark from the instrumental period (Fig. 1, blue arrows). Otherwise the flood mark altitudes (a.s.l.) have to be reconstructed by measurement. Pre-instrumental flood marks may also define the "gauge" of landmarks that were mentioned in pre-instrumental flood descriptions but that were not referred to in the instrumental period (Fig. 1, black double arrows). According to typical local inundations, it may be that certain landmarks were quite commonly referred to over the centuries. If such a commonly referenced landmark could be calibrated e.g. with an instrumentally measured gauge from the 19th century, this gauge can also be used for a flood event that took place several centuries before (Fig. 1, red arrow). But, it imperatively has to be taken into account that major architectural and ground-level changes may occur over time, especially in urban areas. One thus always has to double-check whether the referenced landmark really is the same and was in earlier times in the same condition as it was during the instrumental period when the calibration was carried out. In some cases qualitative calibration does not work because - especially if discharge conditions changed significantly over time - certain landmarks may have only been narratively referred to in the pre-instrumental period, so that calibration with measured gauges is not possible. In those cases reconstructions of the corresponding landmarks, incorporating possible architectonic and ground-level changes over time, need to be conducted. Recourse to archaeological 
and architectural history studies is required to adequately reconstruct the condition of a landmark at the time the flood took place. Not taking into account possible changes could lead to significantly distorted results, especially in urban areas where e.g. ground-level increases of up to several metres may occur over the centuries. Reconstructions of narrative references to landmarks commonly require quite distinct investigative skills to transform them into flood water levels (in $m$ a.s.l.) or discharges, as presented for two Rhine River flood events in Basel: the vicar Hieronymus Brilinger noted in his chronicle that the River Rhine rose so high that people could wash their hands in the water while they were standing on the bridge, which Brilinger did himself when he was a young boy (Hirzel, 1915). The sentence "quod ego ipse feci" (English: "which I did myself") clearly reveals that Brilinger was an eyewitness to the 1480 flood event, and his report can thus be awarded the highest reliability. An anonymous addendum in a chronicle reporting about a flood of the River Rhine in 1424 uses very similar wording to Brilinger, by mentioning that the Rhine rose so high that three pillars of the bridge were destroyed and that people washed their hands in the Rhine (Hirzel, 1890). It is not clear whether people were on the bridge while they were washing their hands in the Rhine, but the close semantic connection between the mentioning of the bridge and the washing of hands supports the conclusion that people may have been standing on the bridge while they washed their hands in the Rhine. This conclusion can be made even more plausible by relating the further referred landmarks to the height of the bridge, as the anonymous addendum additionally reported that boats needed to be boarded through the windows of the guild house of the boatmen and that the Rhine entered the city through the city wall. Figure 2 demonstrates that these references fit well to each other and are (hydro-)logically meaningful. The yellow dotted horizontal line in image a (Fig. 2a) shows that the windows of the guild house of the boatmen is of a similar height to the level of the bridge, both of which must have been more or less reached by the water if people on the bridge were able to wash their hands (as we assumed) and boats needed to be boarded through the window of the guild house (as was explicitly reported). The reference that the water flooded the city behind the city wall supports the assumption that the water level must have more or less reached the level of the bridge as well. The horizontal yellow dotted line in Fig. $2 b$ demonstrates that the city wall would have been submerged if the water had reached the level of the bridge, so that the reported flooding of the city right behind the wall is plausible. Finally, the townscape works of Büchel in Fig. 2a and $b$ are known to feature good closeness to reality (BoerlinBrodbeck and Büchel, 2006).

It has been shown that the water levels of the floods of 1424 and 1480 more or less reached the height of the bridge, as well as the height of the windows of the guild house right beneath the bridge. These references may be used to recon-

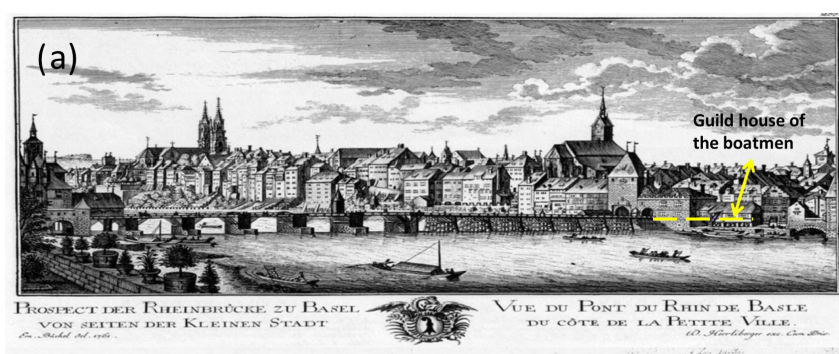

(b)

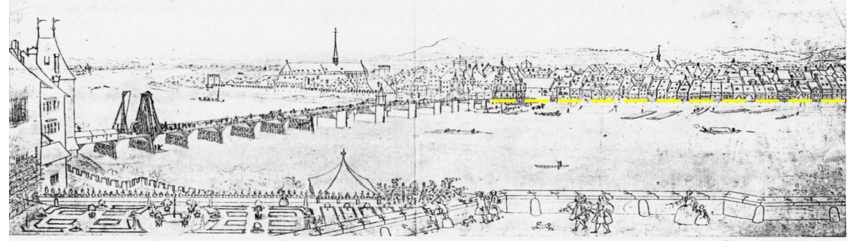

Figure 2. Hydrological plausibility check of referenced landmarks in chronicler reports about the Rhine River floods of 1424 and 1480. (a) Blick auf das linke Rheinufer, 1759; artist: Emanuel Büchel, StABS, Collection Weber-Oeri, Topo 2. (b) Blick vom Rheinsprung auf die Rheinbrücke und Kleinbasel mit Hinterland, 1767; artist: Emanuel Büchel, StABS, Collection Weber-Oeri, Topo 2.

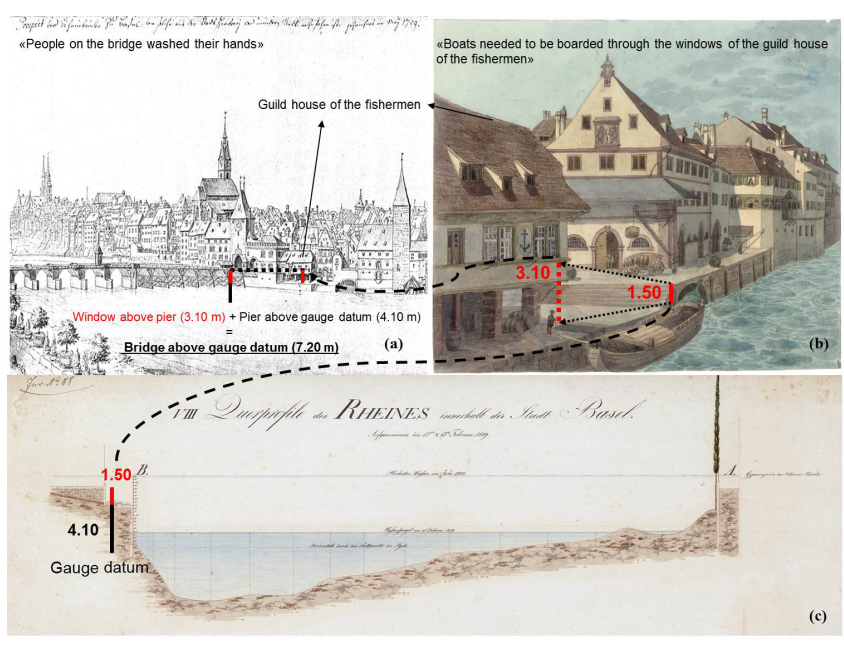

Figure 3. Reconstruction of peak water levels of the 1424 and 1480 River Rhine flood events in Basel based on narrative landmark references (references: levels of the bridge and the windows of the guild house) in combination with a cross profile taken in 1819, right on the spot of the referenced landmarks. (a) Blick auf das linke Rheinufer, 1759; artist: Emanuel Büchel, StABS, Collection WeberOeri, Topo 2. (b) Blick von der Rheinbrücke auf das SchiffleutenZunfthaus; artist unknown, StABS, I 537. Below: Querprofile des Rheines innerhalb der Stadt Basel. Made on 12 and 13 February 1819, StABS, Planarchiv A6, 8.

struct the peak water levels of the two flood events, which was done as presented in Fig. 3.

The height of the windows of the guild house, being on the same level as the bridge (as demonstrated in the left image; Fig. 3, left image), can be reconstructed in metres above 
sea level ( $m$ a.s.l.) based on the gauge being depicted on the cross profile from 1819 (Fig. 3, below on the left). From the depicted gauge we are able to deduce that the difference between the two ground surfaces amounts to $1.50 \mathrm{~m}$. The two ground surfaces are also depicted in the image on the right, showing the landing pier ("Schifflände") seen from the bridge (Fig. 3, right image). As we know the difference between the two ground surfaces, we are now able to assess the height of the window above the lower ground surface by a trigonometric calculation which amounts to $3.10 \mathrm{~m}$ (Fig. 3, right image). Based on the cross profile we furthermore know the difference from the lower ground surface to the gauge datum, which amounts to $4.10 \mathrm{~m}$ (Fig. 3, below on the left). By adding the difference of the lower ground level to the gauge datum $(4.10 \mathrm{~m})$ to the assessed height of the window above the lower ground level $(3.10 \mathrm{~m})$, we finally obtain the height of the window above the gauge datum, which amounts to $7.20 \mathrm{~m}$. The gauge datum, which was installed in 1808 right downstream of the bridge at the landing pier only some metres upstream of the guild house, is known and amounts to $243.93 \mathrm{~m}$ a.s.l. The height of the windows of the guild house thus amounted to approximately $251.13 \mathrm{~m}$ a.s.l. $(243.93+7.20)$. This reconstructed level serves now as the water level for the two flood events from 1424 and 1480 of the Rhine River in Basel. The discharges of the two flood events may then be assessed based on the reconstructed flood water levels (i.e. $251.13 \mathrm{~m}$ a.s.l.) by applying e.g. a one-dimensional (1-D) hydraulic model that calculates the transient 1-D flow integrated over the cross sections of the river systems based on the de Saint-Venant equations (Ven Te Chow, 1973). Discharge quantifications should only be calculated based on cross and longitudinal profiles that may be considered representative of the runoff conditions during the pre-instrumental flood events concerned, so that errors may be kept as small as possible. The cross and longitudinal profiles that were taken in 1819 along the river in the territory of the city of Basel satisfy the prior statement, as the most influential local river engineering measures, like the construction of river banks, were taken much later, at the end of the 19th century. Pfister and Wetter (2011) demonstrated that the approach outlined exemplarily above can be successfully transferred to other sites in Switzerland, which so far has been done for pre-instrumental Sihl and Limmat River flood events in Zürich (Wetter and Specker, 2015; Näf-Huber et al., 2016) as well as for the Aare, Saane and Reuss rivers at different sites alongside the water bodies concerned (Wetter et al., 2015).

\subsubsection{Reconstruction of the long-term frequency and seasonality of minor pre-instrumental flood events}

City accounts belong to a source category with a very high potential for historical hydrological as well as historical climatological analysis, which is why they will now be described in more detail. A special focus shall be laid on the books of weekly expenditures of the city of Basel ("Wochenausgabenbücher der Stadt Basel"). These records were kept from December 1401 to April 1799 in 84 volumes. Unfortunately some volumes are missing, including the records for the years 1408-1409, 1434-1451 and 16191621 . The records are dated on a weekly basis, meaning that the date accuracy of the single records is somewhat distorted. The books of weekly expenditures were first analysed by Fouquet (1999), who found recurring records of wage expenditures for a squad of craftsmen who were called up onto the bridge of the Rhine River with the task of preventing it from being damaged by manoeuvring the drifting logs from the flood waters around the vulnerable wooden pillars. Even though Fouquet's research interest did not have a historical hydrological focus, he was able to show a large number of River Rhine flood events. Sixty-eight floods for the period from 1456 to 1542 were identified, whereas chroniclers only recorded seven events during the same period. This ratio of almost $10: 1$ points to significantly sharper "observation skills" of the weekly records of expenditures for smaller flood events, which may be explained by the fact that bridges can be endangered by relatively small events, whereas on the other hand it is known that chroniclers as well as journalists generally focus on the spectacular (i.e. extreme) flood events. A closer, specifically historical hydrological examination of this source reveals that the "observation skills" for small River Rhine flood events is even much better than one could assume, according to the findings by Fouquet (1999), and that the weekly records also include a vast number of expenditures (records) in the context of further local water bodies, like the Wiese River and the Birsig brook. These latter records are given in the form of wages for gatekeepers to open the fence at the brook's entry into the city through the city wall, with the goal of preventing damming by floating debris during flood events. Sometimes these accounting records even allow the assessment of flood durations, as they mention how many day and night wages for the guarding of the bridge or the fences at the city wall were paid. The books of weekly expenditures of Basel additionally include information about weather-related damages in Basel's sphere of influence or even in further away locations of importance. In the following example from a record dated on 15 September 1607 the council donated GPB 2 and $10 \beta$ to two persons from its confederate ally Lucerne, who suffered losses because of the water (i.e. flood). The weekly books of expenditures furthermore contain expenditures for hay and aftergrass harvests at municipal meadows. Spycher (2017), who compared these harvest dates with monthly resolved precipitation and temperature anomalies from Pfister (1998), found significant correlations between early and late onsets of hay and after-grass harvest dates and the preceding months with dry or moist weather anomalies. According to her findings, above-average moist or dry conditions in the period from April to June (AMJ) correlate with late (moist) or early (dry) 
hay harvests, whereas above-average July-August (JA) conditions result in late (moist) or early (dry) after-grass harvests. Similar analysis by Wetter (unpublished) revealed that hay harvest dates, if they are dated on a daily accuracy level (unlike the hay and after-grass harvest dates from the books of weekly expenditures), significantly correlate with anticyclonic weather conditions if they are compared to a \pm 3 -day temporal context around the corresponding hay harvest dates. This temporal correlation between hay harvest and anticyclonic weather situations, which usually correlate with sunny weather, can be plausibly explained, as the grass - after hay harvest - needed to be dried on the field before it could be collected and stored in the barn. Farmers were generally good interpreters and predictors of local weather, as not only hay harvest but also many other agricultural activities directly depended on these short-term weather situations. The narrative information given from these accounting records is by no means adequate enough, either to assess flood magnitudes by applying an index-based approach or to reconstruct flood water levels. Their strength instead lies in the detection of minor and normal, so far unknown, pre-instrumental flood events and the ability to date them at a weekly, monthly or seasonal resolution. They furthermore allow the definition of a minimum discharge threshold when protection measures like the guarding of the bridge or the opening of the fence at the gate were usually ordered and carried out. The dating of the floods recorded in the books of weekly expenditures of Basel is not as simple as one might think because the records are dated only on a weekly basis, which makes an exact assignment to a month uncertain in certain cases. This uncertainty arises when, after the calendar correction has been made, the weekly dated expenditures (a list of expenditures that is dated every Saturday) overlaps 2 months, as in these cases one cannot be certain in which month the recorded flood event actually took place. In these cases we are dependent on likelihood estimations which we apply as explained by the following example: if the calendar corrected date was Saturday 29 July, it is somewhat more likely that the recorded flood took place in August than in July because there are 3 possible days of the flood event in July (29 to 31 July) compared to 4 probable days in August (1 to 4 August). In this special case the flood would thus be assigned to August. In other words the recorded flood events will always be assigned to the month which has mathematically more potential for a flood event (simply by having more possible days when the flood event could have taken place). Incorrect month assignment cannot be excluded with this approach, but in the long run these errors should abrogate each other. Municipal accounts that are dated only on a half-year level do not have this dating accuracy problem as there are no overlaps between the two half-year periods if the two periods begin, as they usually do, on 1 January (first half-year period) and on 1 July (second half-year period). Some half-year dated municipal accounts might start - according to another manner of dating more related to agricultural interests - the first period on 1 March (first period 1 March to 31 August), whereas the second period starts on 1 September but ends on 28 or 29 (leap years) February in the next year. If there is no additional singular dating of records in the second period, it is impossible to disentangle whether the recorded floods from the second period still appeared in the "old" year or already in the "new" year. For future analysis it is therefore strongly recommended to focus predominantly on weekly and, in second priority, on half-yearly municipal accounts, where both periods are in the same year.

\subsubsection{Reconstruction of pre-instrumental drought events}

Historical documentary sources including information about drought events are quite rare compared to the numerous sources that provide information about flood events. This is explained by the fact that meteorological droughts, defined as a lack of precipitation over a large area and for an extensive period of time (e.g. Sheffield et al., 2012), do not occur as frequently in central Europe as flood events, which compared to droughts may be local, are often spectacular and may cause in a short time considerable loss and destruction, all of which is predestined to attract the attention of contemporary chroniclers or journalists. Meteorological droughts on the other hand develop slowly, are for a long time completely unspectacular, and therefore in that phase generally are not recognised by most contemporaries. Only when the meteorological droughts gave rise to agricultural droughts (defined as insufficient soil moisture to support crops; Seneviratne et al., 2012) and/or socio-economic droughts (defined as all sorts of direct and indirect impacts on humans and society; e.g. Heim, 2002) did chroniclers usually begin to report, mainly on negative societal and economic impacts, as the resilience of these pre-industrialized, mainly agricultural and often rather regional-trade-based societies probably was quite a bit weaker towards these, for central $\mathrm{Eu}-$ rope, rather unusual hydrological extreme events, than towards much more routinely occurring flood events. In the cases of severe drought events, e.g. during the perennial heat and drought of 1540, many chroniclers tried to describe the drought's severity as accurately as possible by objectivising their descriptions with observations about the impacts on the physical and biological environments. Contemporaries often described very low water levels of water bodies in such a way that they can be reconstructed. They furthermore made reference to extreme soil desiccation by describing the wideness and deepness of soil cracking or described the leaf fall of vines and trees to objectivise the severity of the heat and dryness. Observations about unprecedented early vine harvest allow the assessment of the magnitude of the mean springsummer temperature anomaly, which in the case of 1540 was assessed to have amounted to around $+6{ }^{\circ} \mathrm{C}$ (between 4.7 and $6.8^{\circ} \mathrm{C}$ ) compared to the 20th century mean (Wetter and Pfister, 2013). Several independent chroniclers reported on 


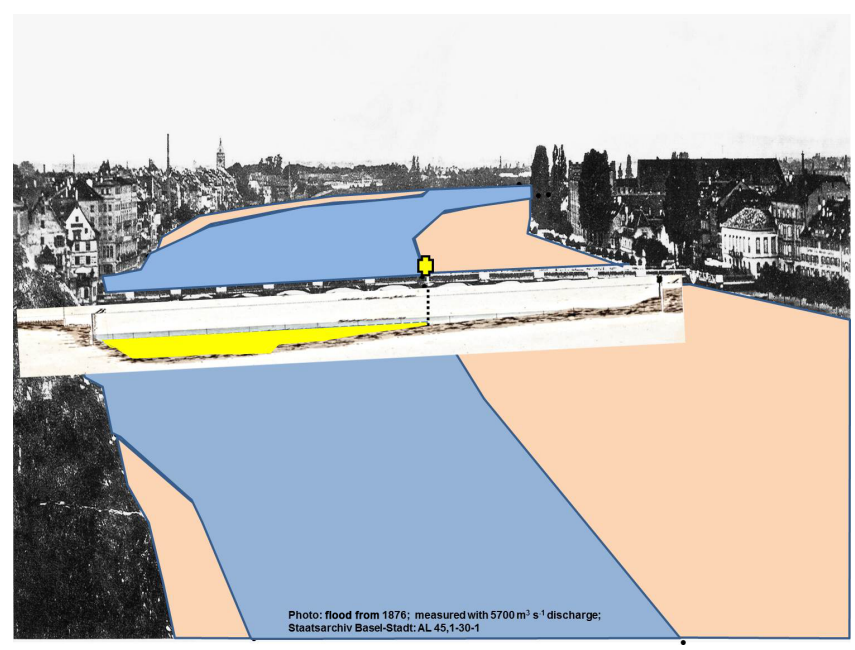

Figure 4. Reconstructed Rhine River channel during the peak of the perennial drought in 1540 .

the number of days with precipitation in 1540 , which permits the assessment of the precipitation amount on a seasonal and annual level as the number of days with precipitation (NDP) and the seasonal and annual precipitation amounts (PAs) are highly correlated. Reconstruction of low water levels and the assessment of discharges in principle work similarly to flood reconstructions. The principal methodology will be shown in the following example: the chronicler Adelberg Meyer (Basler Chroniken, 1902) described the situation for the Rhine River in Basel. He referenced his description to the built environment like the bridge, the cathedral and the confluences of the rivers Birs and Rhine. Meyer reported that the Wiese River was completely dry, whereas the Birs and Rhine rivers were very low. The right river bank of the Rhine was dry up to the position of the little chapel, which was installed on the fourth pillar of the bridge (Fig. 4, yellow cross). The left river bank was dry from the confluence of the Birs and Rhine rivers (more than $2 \mathrm{~km}$ upstream of the bridge) up to the position of the cathedral, less than $400 \mathrm{~m}$ upstream of the bridge. Including the information given from downstream of the bridge, the approximate 1540 river channel, where water was still flowing, could be reconstructed as illustrated in Fig. 4. The line of the reported river channel is hydrologically consistent as the cross profiles from upstream of the position of the cathedral suggest a small dry left river side during extremely low water levels because of its steepness, whereas the right river side should be largely dry because of its broad shallow shapes. The Rhine River makes a strong bend to the right after the position of the cathedral, which is why the water carved out the profile there deeply, and explains why in this part the river was still flowing during the peak of the 1540 low water level.

The reconstructed low water river channel of the 1540 flood was then rendered to the cross profiles that were taken

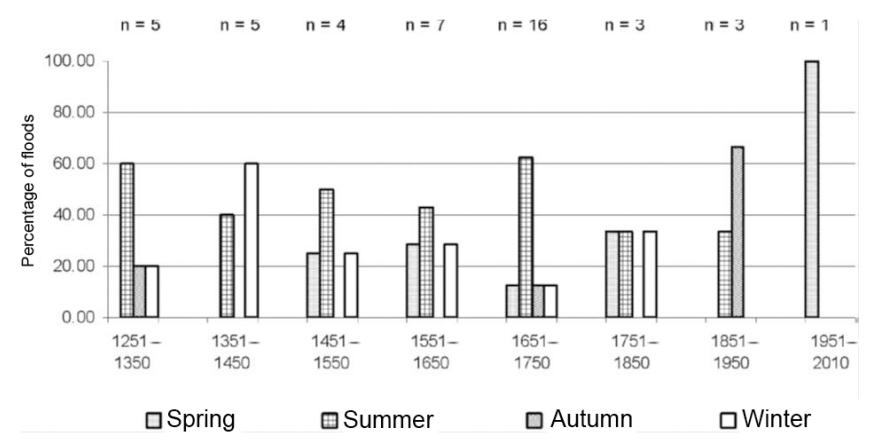

Figure 5. Seasonality of Rhine River flood events for the period 1250-2010 in Basel $\geq 5000 \mathrm{~m}^{3} \mathrm{~s}^{-1}$ (Wetter et al., 2011).

in 1819 from which finally the discharge could be deduced (Fig. 4, yellow array in the cross profile).

\section{Results}

\subsection{Reconstruction of the long-term frequency and seasonality of hydrological extreme events}

Long-term frequency and seasonality reconstructions of hydrological extreme events can be conducted after necessary calendar style corrections have been made. Figure 5 demonstrates the seasonality of Rhine River flood events in Basel $\geq 5000 \mathrm{~m}^{3} \mathrm{~s}^{-1}$ discharge.

The definition of the seasonality resolution and subperiodisation is completely up to the analyser's discretion. It can be done as shown in the figure above, including the $5000 \mathrm{~m}^{3} \mathrm{~s}^{-1}$ threshold, or e.g. in a more binary approach that only distinguishes between flood and no flood or drought and no drought (evidence). Figure 6 illustrates long-term changes in the Rhine River flood occurrences above a discharge threshold of $\geq 4300 \mathrm{~m}^{3} \mathrm{~s}^{-1}$ in Basel, showing an increase in the second half of the 17th century and a significant gap of extreme events at the end of the 19th and during almost the whole of the 20th century.

Flood frequency changes like this, whatever the reason might be, do have significant consequences for the assessment of recurring periods of extreme events. A well-known consequence of the extrapolation from short (instrumental) series is the high level of uncertainty associated with estimates of design floods with large return periods. For example, estimating the 100-year design flood peak from a 24 -year record, Stedinger and Griffis (2011) reported a factor of 4 to 1 between the upper and lower bounds of the $90 \%$ confidence interval. Figure 7 demonstrates the impact of the inclusion of reconstructed flood events from the pre-instrumental period on the result of flood frequency analysis. First of all the inclusion of the reconstructed pre-instrumental period flood events significantly expands the reliable extrapolation range from a 200-year flood event (based on the instrumen- 


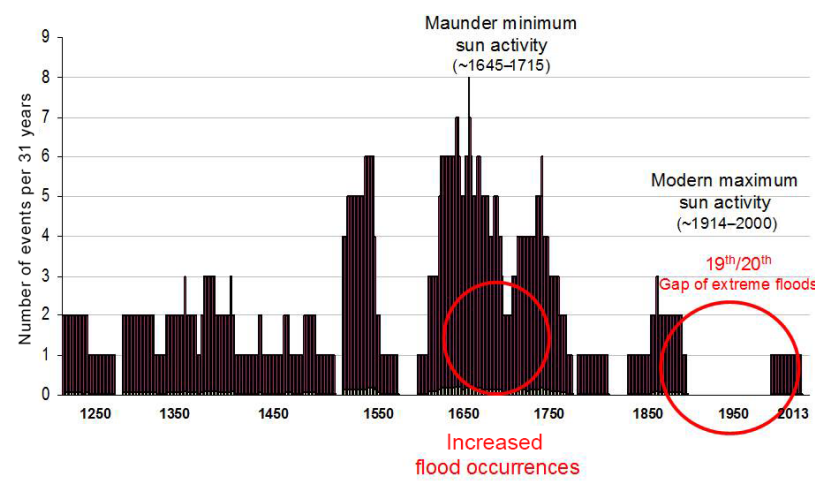

Figure 6. Thirty-one-year running mean of extreme Rhine River flood events $\left(\geq 4300 \mathrm{~m}^{3} \mathrm{~s}^{-1}\right)$ in Basel.

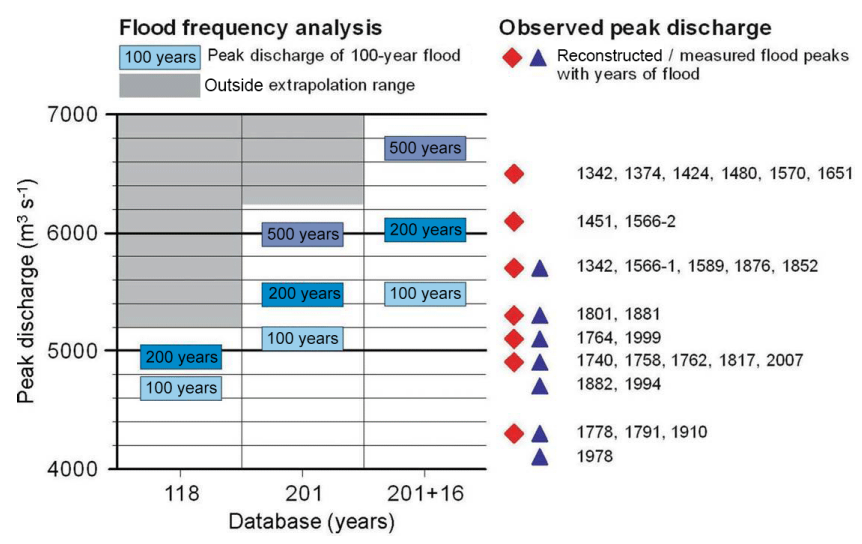

Figure 7. Flood frequency analysis based on the official reference period (1891-2008), the full instrumental period (1808-2008) and the full instrumental period plus 16 reconstructed pre-instrumental flood discharges for the Rhine River in Basel.

tal period only) to a 500-year flood event. Secondly, the discharge magnitudes e.g. of 200-year flood events significantly increase from less than 5000 to more than $6000 \mathrm{~m}^{3} \mathrm{~s}^{-1}$. It has to be stated that the discharge values have been included in the frequency analysis as they were observed and reconstructed, which means that no adjustments of pre and post river regulated conditions have been established, which very likely distorted the results of the increased flood discharge magnitudes significantly. This point will be discussed later in detail in Sect. 4.3.

\subsection{Index-based magnitude reconstruction of extreme pre-instrumental hydrological events}

So far the approach of the ongoing historical hydrological research (Swiss National Science Foundation project, 2014-
$2017)^{2}$ has not been focussed on index-based flood magnitude reconstructions, but it will definitely be considered after the water level and discharge reconstructions of major Swiss rivers have been completed, so comparatively much more flood evidence may be included in long-term hydrological analysis. According to Kjeldsen et al. (2014), indexed preinstrumental flood events are a useful tool for categorising and visualising flood magnitude, but the approach has yet to be useful in the estimation of flood frequency, as it removes individual event information and groups the events, thereby reducing the potential value of the data. By combining indexed flood events with observed discharges, this handicap can partially be overcome. Figure 8 shows an example of a four-step index flood magnitude reconstruction for the Vltava River in Prague (Brázdil et al., 2006). This approach combines indices with observed discharges and assumes, based on informed expert judgement, that the thresholds of flood indices $0,1,2$, and 3 correspond to floods with 2- (Q2), 10(Q10), 50- (Q50), and 100-year return periods (Q100).

A similar kind of approach should be applicable for Switzerland as well. The goal will be to combine indexed flood events, reconstructed flood levels and discharges, as well as indirect flood data from municipal accounts with observed flood events from the instrumental period. It is not possible to reconstruct flood levels or discharges based on indirect flood data from municipal accounts, but it is indeed possible to assess a minimum discharge threshold by comparing the number of municipal account flood records with the instrumental observation series and calculating the ratio (on the assumption that the flood frequency is comparable between the two series) from which the minimum discharge or water level can finally be deduced from the instrumental series. This minimum discharge seems to have been the threshold for the person in charge (i.e. the bridge-master or gatekeeper) to take precautionary measures to protect the corresponding infrastructure against possible flood damages, which finally found its entry into the municipal accounts in the form of records about paid wages for the executive staff.

\subsection{Water-level- or discharge-based reconstruction of extreme pre-instrumental hydrological events}

Figure 9 illustrates the results of the discharge reconstructions of the Rhine River flood events in Basel, showing a significant trend of decreasing flood magnitudes since the beginning of the 18th century. A more sophisticated analysis reveals that this "trend" is in truth a two-step decrease which was caused by two major anthropogenic river engineering interventions in the large-scale catchment area, which significantly changed the discharge budget, especially in the case of extreme flood events. The timing of the redirections of the River Kander to Lake Thun in 1714 (Vischer, 2003) and of

\footnotetext{
${ }^{2}$ SNF project 153327: Reconstruction of the genesis, process and impact of major flood events of major Swiss rivers including a peak discharge quantification.
} 


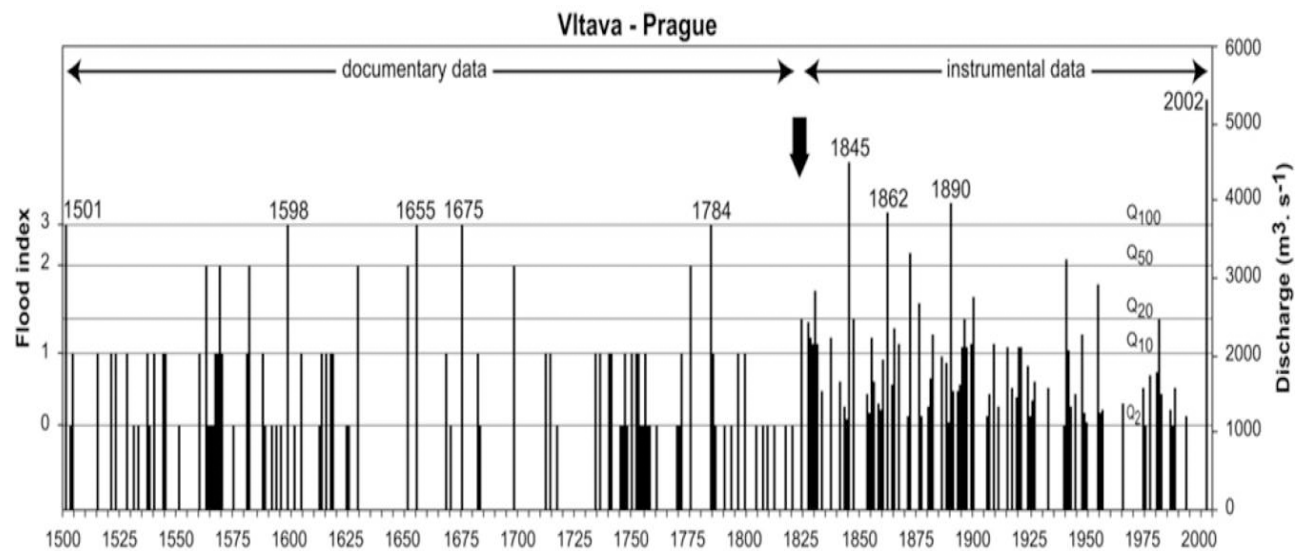

Figure 8. Index-based flood magnitude reconstruction for the Vltava River in Prague (Brázdil et al., 2006).

the River Aare to Lake Biel in 1878 (Przegon, 1999) clearly correlates with the decreased flood magnitudes of the River Rhine in Basel. The additional retention capacities of the two lakes significantly decelerates the flood waves, which before the redirections just rushed through the rivers Kander and Aare and finally reached the River Rhine in Basel without being significantly decreased before.

The two-step flood magnitude decrease for the River Rhine at Basel is confirmed by other flood reconstructions at sites at the Aare and Rhine rivers downstream of the two redirections, whereas no long-term change in flood magnitudes can be detected at the Rhine River above the confluence with the Aare River. This result is plausible as Lake Constance as well as the corresponding section of the Rhine River were never subject to river engineering measures that could have significantly influenced the runoff characteristics. The difference in flood magnitudes at the different flood reconstruction sites along the Aare and Rhine, on the other hand, are comparable with each other, which should thus allow an assessment of the long-term mean retention capacities of the two lakes (lakes Thun and Biel), which provide the opportunity to homogenise the pre-redirection flood events (i.e. the floods that took place in the period before the rivers Kander and Aare were redirected to lakes Thun and Biel) to the actual runoff regime (paper in progress). The influence of anthropogenic river engineering measures on runoff conditions and flood water levels is obvious for Lake Zürich and the Limmat River as well, with three steps of decreased flood water levels. The first step occurs after the works at the city trench (Schanzengraben) were finished in 1677, which created, apart from the Limmat River, an additional runoff for Lake Zürich. The second step occurred after the Linth River was redirected to Lake Walen in 1816, which significantly decreased flood level magnitudes in Zürich due to the retention capacity of Lake Walen. The last step occurred in the early 1950 s when the weir for power and regulation purposes was constructed. Note that Fig. 10, unlike Fig. 9, demonstrates flood levels.

Figure 11 demonstrates the assessment of the long-term changes in runoff conditions of the Limmat River in Zürich, taking into account all (reconstructable) local and regional anthropogenic interventions influencing the runoff conditions.

The numerous anthropogenic interventions influencing the runoff conditions were quantified in a semi-quantitative approach. The quantification is based on a 12-point index scale, where 6 stands for a very strong runoff, 1 for a very weak declined runoff, +6 for a very strong runoff and +1 for a very weak increased runoff at Zürich. Figure 11 shows numerous anthropogenic interventions, each causing only very weak declined (Fig. 11, blue graph) runoff conditions, but taken together (Fig. 11, red graph) the declined runoff conditions in the period from the 14th to early 19th centuries were significant. The most significant increase in runoff conditions was realised in the context of the Linth River correction in the early 19th century, when the main tributary of the Limmat River was redirected to Lake Walen and most river damming installations in Zürich were withdrawn from the Limmat River.

Figure 12 demonstrates the flood level development of extreme events in Lucerne for Lake Lucerne and the Reuss River, showing either a weak trend towards slightly smaller flood levels or simply a poor period of extreme floods, if the flood event from 1817 is excluded from the analysis: 1817 is by far the most extreme event in the last 7 centuries, which is also true for Lake Constance. This correlation of the two most important lakes right on the edge of the Swiss Alps is not coincidental and is directly linked to the so-called year without a summer of 1816 (e.g. Luterbacher and Pfister, 2015). A significant cooling and change in precipitation patterns occurred in 1816 in Europe, mainly due to the large amounts of $\mathrm{SO}_{2}$ emissions into the atmosphere caused by the massive eruption of Mount Tambora in the tropics (Luter- 


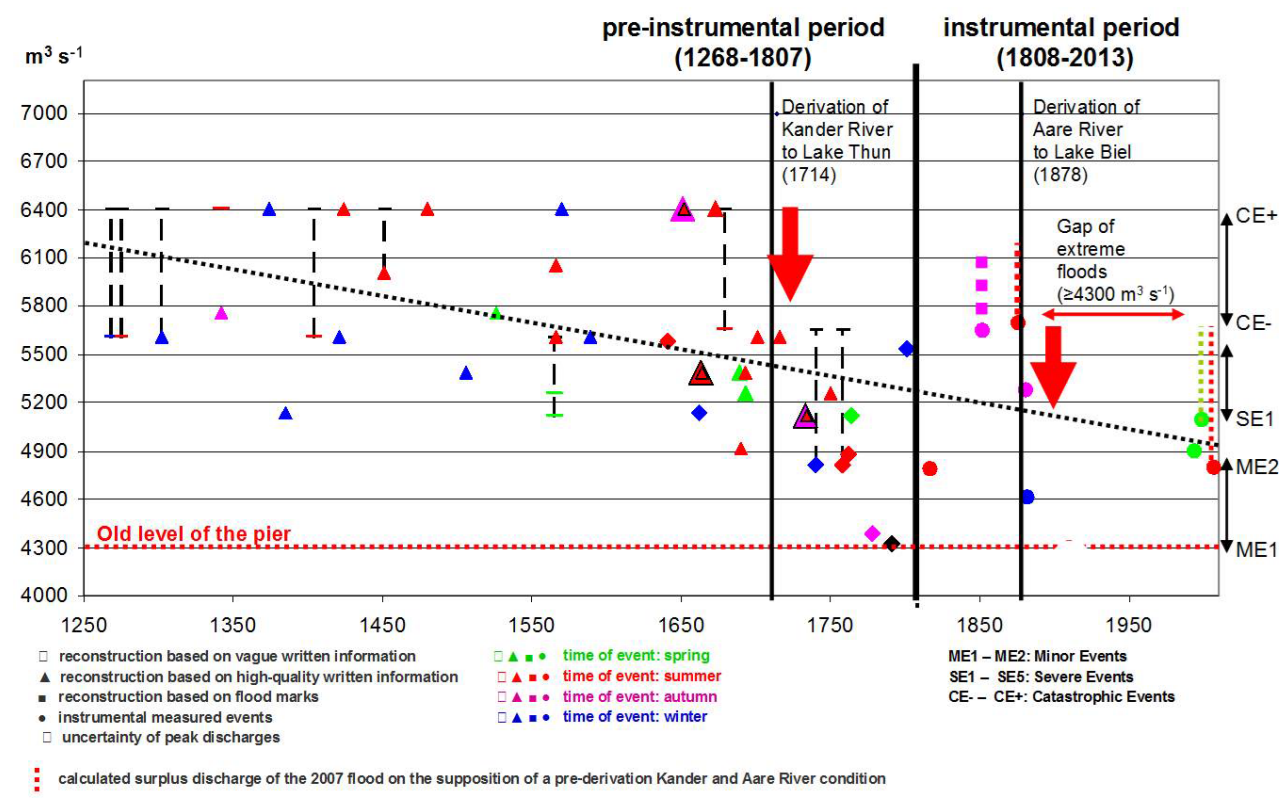

Figure 9. River Rhine discharges in Basel for the period 1250-2010 (Wetter et al., 2011).

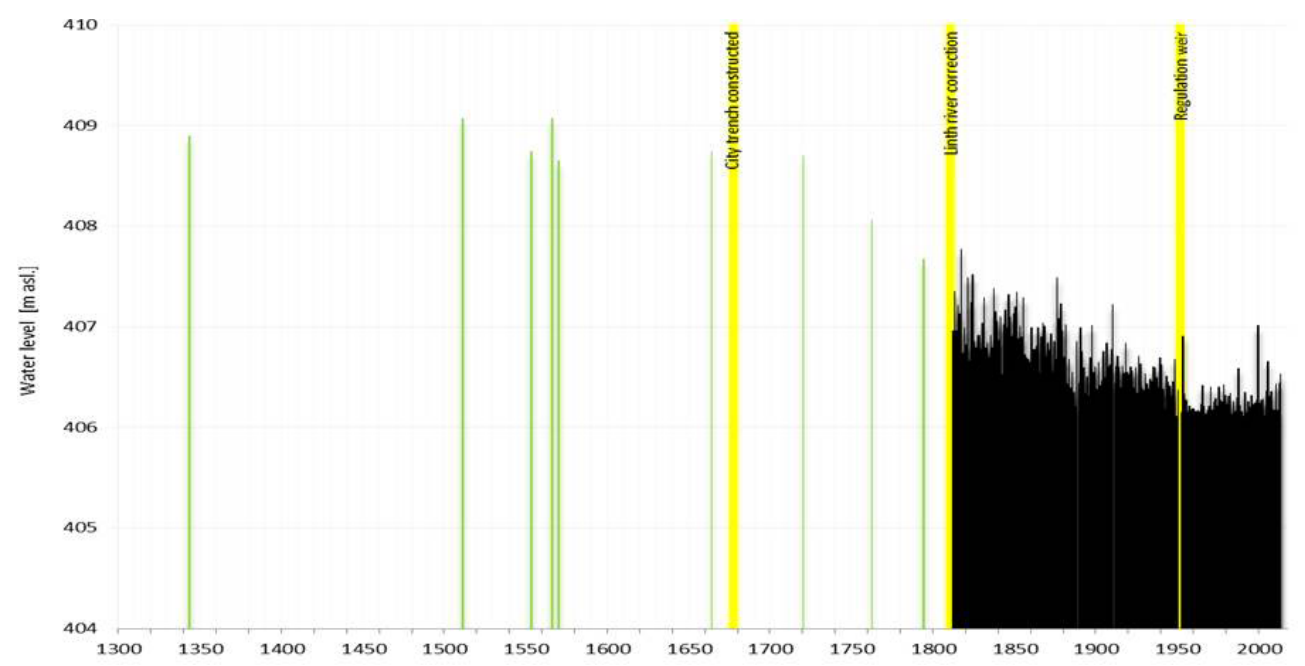

Figure 10. Three-step decrease in flood magnitudes for Lake Zürich and the River Limmat in Zürich (Näf et al., 2016; Wetter and Specker, 2015).

bacher and Pfister, 2015). Precipitation (especially but not exclusively in the Alpine region) fell as snow, sometimes even in summer, and the stored snow masses from winter $1815 / 1816$ did not melt in the Alps due to the overall cool temperatures. The second layer of snow, in chronological order, was added throughout the year 1816, due to snow instead of rainfalls in the Alpine region. The first two layers were then again superimposed by the $1816 / 1817$ winter snow precipitation. In spring and summer 1817 massive amounts of melting water accumulated in Lake Lucerne and Lake Constance due to three melting snow layers instead of only one melting snow layer. The runoff conditions of the River Reuss in Lucerne have only marginally increased during the last 7 centuries, which might explain the somewhat smaller flood levels since the construction of the Lake Lucerne regulation weir in 1861, again not taking into account the 1817 event (Fig. 13).

The decrease in flood magnitudes gets a bit more obvious if the dammed water level of Lake Lucerne is taken into account. According to Küng (2006), the normal water level of Lake Lucerne was intentionally dammed by a Medieval weir to provide enough water to run the mills on the Reuss River. Since then this weir has been gradually heightened to withstand the pace of the increasing amount of water required by 


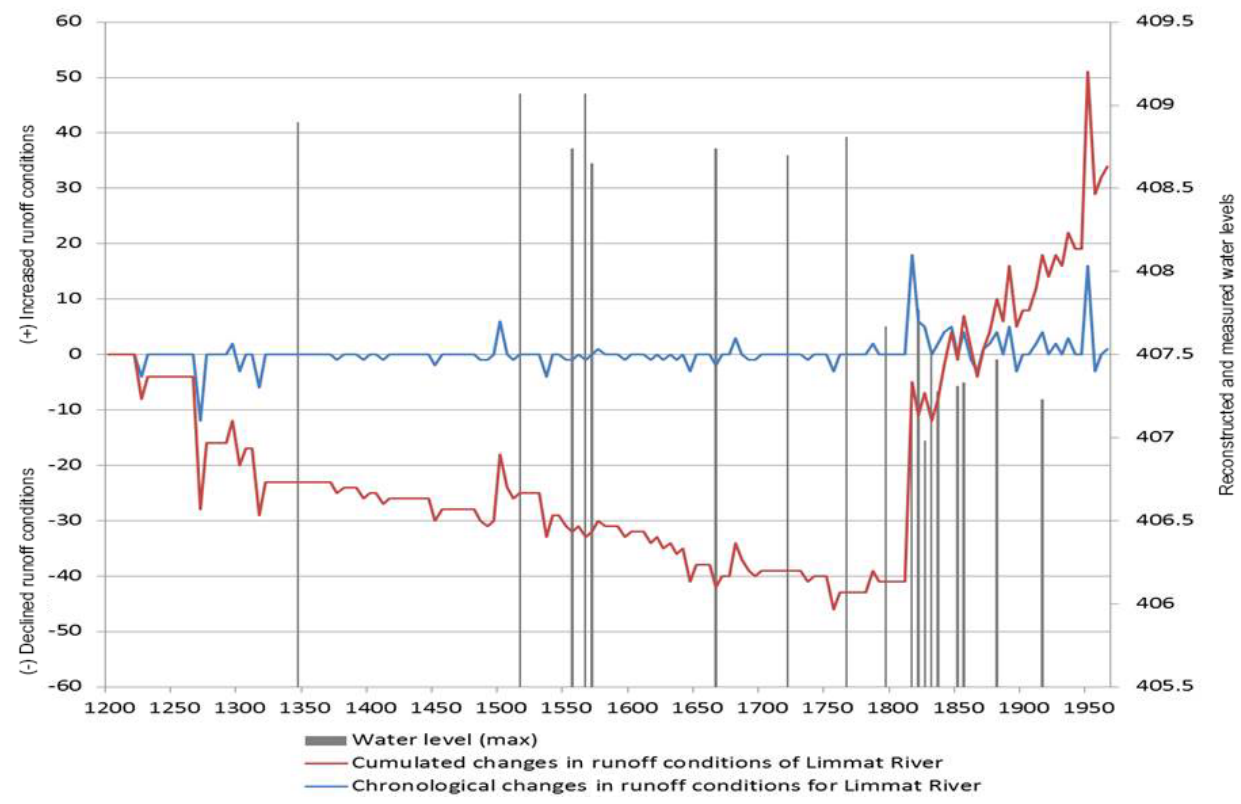

Figure 11. Changes in runoff conditions of the Limmat River in Zürich.

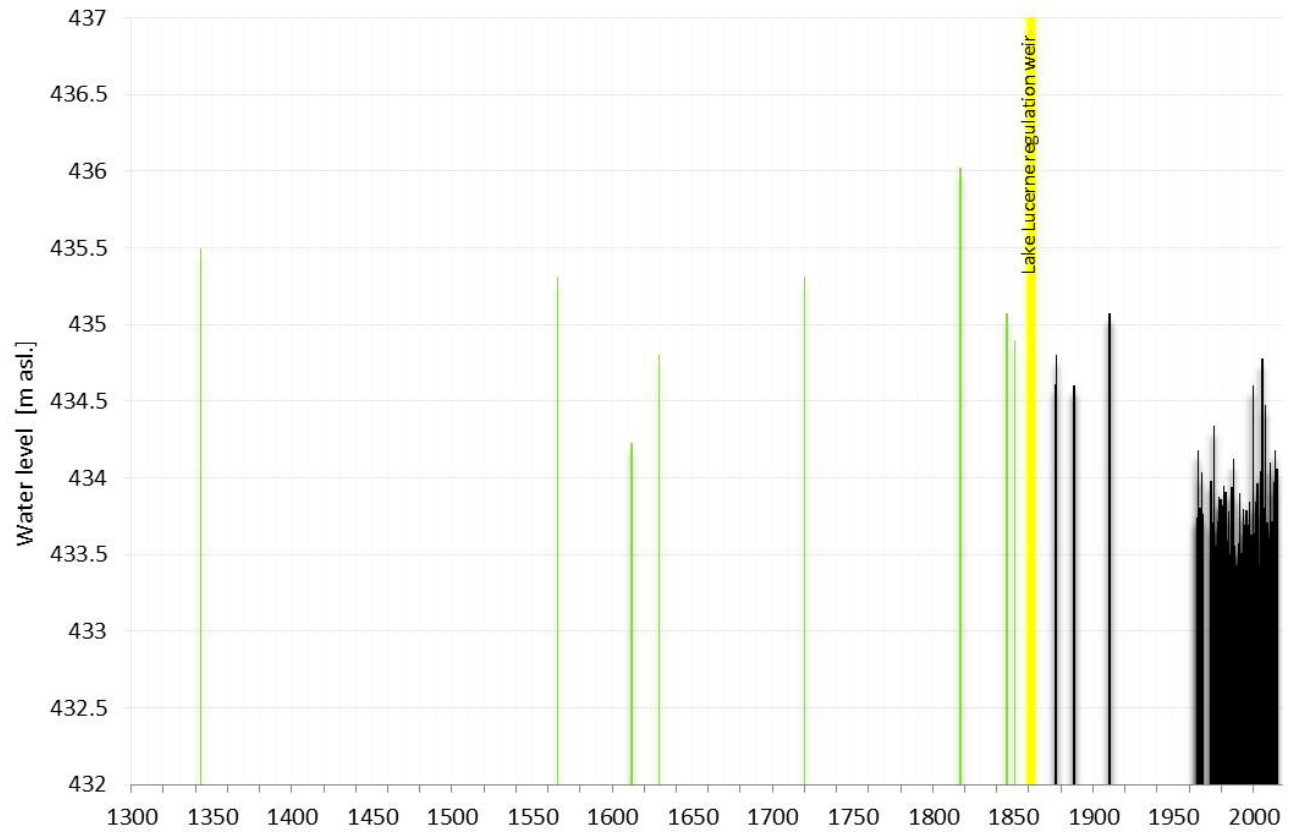

Figure 12. Long-term stationarity of Lake Lucerne and Reuss River extreme flood water levels (Wetter et al., 2015) or slow trends of decreasing flood magnitudes (?). Green bars: reconstructed flood levels above sea level (a.s.l.). Black bars: measured flood levels a.s.l. Yellow bar: significant anthropogenic intervention in the discharge conditions.

the mills in the following centuries. Due to the constantly increased lake water level, subsequent floods needed less water to reach the same water level as earlier flood events. In terms of figures this difference of the normal lake water levels can be corrected from the flood level, which results in a more obvious decrease in flood magnitudes. This was most probably caused by a more sophisticated lake water level regulation technique since the construction of the regulation weir and the removal of mills from the Reuss River in the 19th century coupled with excavation of the river bed in the 21 st century (Paravacini, 2013). No major river engineering interventions, except for the construction of dams in the Alps, were realised 


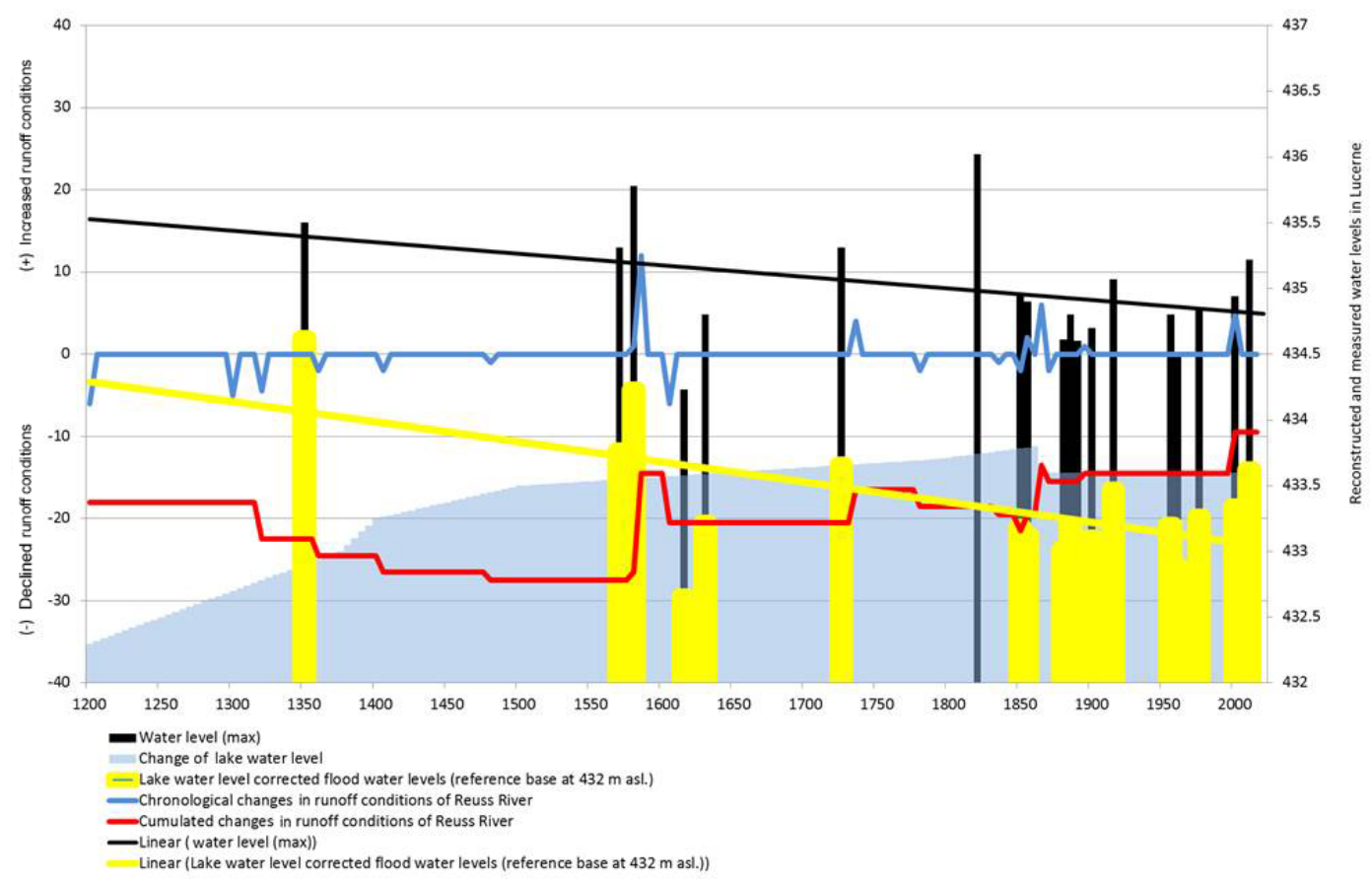

Figure 13. Significant increase in normal Lake Lucerne water levels versus a slight increase in Reuss River runoff conditions over the last 7 centuries.

in the upstream Reuss River catchment that could have significantly changed the regional and local runoff conditions in Lucerne. Note that so far only flood water levels are at hand as discharge calculations could not yet be performed.

\subsection{Precipitation and temperature reconstruction to evaluate important drivers of extreme hydrological events}

Climate parameters like temperature and precipitation are the main drivers of extreme hydrological events (i.e. drought and flood events). Chroniclers, reporting events, mainly focus on the description of (material) losses, negative impacts on the economy and society and, in the case of floods, quite often on the magnitude of the event (i.e. references to the water level and submerged area), whereas triggers of extreme hydrological events are rarely described. If the events are extraordinarily extreme, science-oriented explanation may be provided comparably more often, and mostly with a quite useful, substantial and informative quality. The Bernese chronicler Diebold Schilling (1445-1486) described the triggers of the 1480 flood event, probably the most extreme flood of the Aare River in the last 7 centuries (Pfister and Wetter, 2011), in the following science-oriented manner: 3 days and nights of uninterrupted heavy rainfalls heralded the start of this extraordinarily extreme flood event that took place on 1 August 1480. Schilling additionally provided important information about the "pre-disposition" by stating that there was a distinct warm phase in the run-up to the extreme precipitation event, which rapidly melted the glaciers and stored snow in the Alps. From other sources it is known that the spring and early summer were exceedingly wet and, in the Alps, rich in snow. By combining the information we have enough contemporary and reliable evidence to conclude that the trigger of the 1480 flood event was warm weather, snowmelt combined with $72 \mathrm{~h}$ of uninterrupted heavy rainfalls. In the case of opposite hydrological extreme events, e.g. the severe heat and drought in 1540, chroniclers not only provided useful information on low water levels, but also began to numerate the few days with precipitation in that year. Figure 14 presents the reconstructed number of days with precipitation (NPD) in 1540 for Cracow (Poland) on the left and Switzerland on the right.

The reconstructed NPD for Cracow and Switzerland is considerably lower than that of the 20th century average and even below the successive absolute minima of spring, summer and autumn of the instrumental period since 1864. Figure 15 demonstrates the cumulated deviation of the NPD compared to the 20th century mean (Fig. 15b; dotted line: 20th century mean versus black line: NPD of 1540) which amounted to $81 \%$ fewer days with precipitation in Switzerland. The precipitation amount (PA) was calculated according to the methodology developed and discussed in Wetter et al. (2014) which, simplistically expressed, is based on the close correlation between the NPD and PA (Fig. 15a). The calculated 1540 PA for Switzerland was significantly below the 100-year minimum levels throughout spring (MAM), summer (JJA) and autumn (SON). No similar event is doc- 


\begin{tabular}{|c|c|c|c|c|c|c|c|c|c|c|c|c|c|c|c|c|c|c|c|c|}
\hline$\overline{\text { DAY }}$ & JAN & FEB & MAR & APR & MAY & $\pi \mathrm{JN}$. & JUL & AUG & SEP OCT & NOV DEC & JAN FEB & MAR & APR & MAY & JUN JUL & AUG : & SEP 0 & $\overline{\mathrm{OCT}} \mathrm{N}$ & NOV 1 & $\overline{\mathrm{DEC}}$ \\
\hline 1 & snow & & & & rain & & & & & & $\mathrm{N} / \mathrm{A}$ & & & & & & & & & \\
\hline 2 & snow & & & & & & & & & & N/A & & & & & & & & & \\
\hline 3 & snow & & & & & rain & rain & & & & N/A & & & & & & & & & \\
\hline 4 & snow & & & & & & & & rain & & N/A & & & & & & & & & \\
\hline 5 & snow & & & & rain & & & rain & rain & & N/A & & & & & & & & & \\
\hline 6 & snow & & & & & & & & & snow & $\begin{array}{l}\text { N/A } \\
\text { N/A }\end{array}$ & & & & & rain & & & & \\
\hline $\begin{array}{l}7 \\
8\end{array}$ & snow & & & & & & & & & & $\mathrm{N} / \mathrm{A}$ & & & & & rain & & & & \\
\hline 9 & snow & snow & & & rain & & & rain & & & N/A & & & & & rain & & rain & & \\
\hline 10 & rain & snow & & & & rain & & rain & & & $\mathrm{N} / \mathrm{A}$ & rain & & & & rain & & rain & & \\
\hline 11 & rain & snow & snow & rain & & rain & & & & & $\mathrm{N} / \mathrm{A}$ & rain & & & & rain & & & & rain \\
\hline 12 & rain & & snow & & rain & & & & rain & & $\mathrm{N} / \mathrm{A}$ & rain & & & & rain & & & & \\
\hline 13 & & & & & rain & & & rain & & & N/A & & & & & rain & & & & \\
\hline 14 & & & & & & rain & & $\begin{array}{c}\text { rain } \\
\text { tempest }\end{array}$ & & & $\mathrm{N} / \mathrm{A}$ & & & & & rain & & & & \\
\hline 15 & & & & & & & & & & & N/A & & & & & rain & & & & \\
\hline 16 & & & & & & & & & & & $\mathrm{~N} / \mathrm{A}$ & & & & & rain & & & & \\
\hline 17 & & snow & & & & & & & rain & & N/A & & & & & & & & & \\
\hline 18 & & snow & & & & & rain & & rain & & N/A & & & & rain & & & & & \\
\hline 19 & & & & & & & rain & & & $\dagger$ & $\mathrm{N} / \mathrm{A}$ & & & & rain & & & & & \\
\hline 20 & & & & & & & & & & & $\mathrm{~N} / \mathrm{A}$ & & & rain & rain & & & & & \\
\hline 21 & & & rain & & & rain & & & & & $\mathrm{N} / \mathrm{A}$ & & & & rain & & & & & \\
\hline 22 & & & snow & & rain & & & & & & $\mathrm{N} / \mathrm{A}$ & & & & rain & & & & rain & \\
\hline 23 & & & & & & & rain & & & & N/A & & & & & & & & & \\
\hline $\begin{array}{l}24 \\
25\end{array}$ & & $\begin{array}{l}\text { nnow } \\
\text { snow }\end{array}$ & rain & & rain & & $\begin{array}{l}\text { rain } \\
\text { rain }\end{array}$ & & & & $\begin{array}{l}\text { N/A } \\
\text { N/A }\end{array}$ & & & & & & rain & & & \\
\hline 26 & & snow & & & & & & & & & $\mathrm{N} / \mathrm{A}$ & & & & & & & & rain & \\
\hline 27 & snow & & & & rain & & & & rain & & N/A & & & & & & & & rain & \\
\hline & & & rain & & & & & & rain & & N/A & & & & & & & & rain & \\
\hline 29 & & & rain & & rain & & & & rain & & N/A & & & & & & & & rain & \\
\hline 30 & & & & rain & & & & & & & $\begin{array}{l}\text { N/A } \\
\text { N/A }\end{array}$ & & & & & & & & & \\
\hline
\end{tabular}

Figure 14. Number of days with precipitation (NPD) in Cracow (left) and Switzerland (right) derived from the weather diary of Marcel Biem (left) and from chroniclers situated in Switzerland and nearby Alsace and southern Germany (Wetter et al., 2014; Supplement).
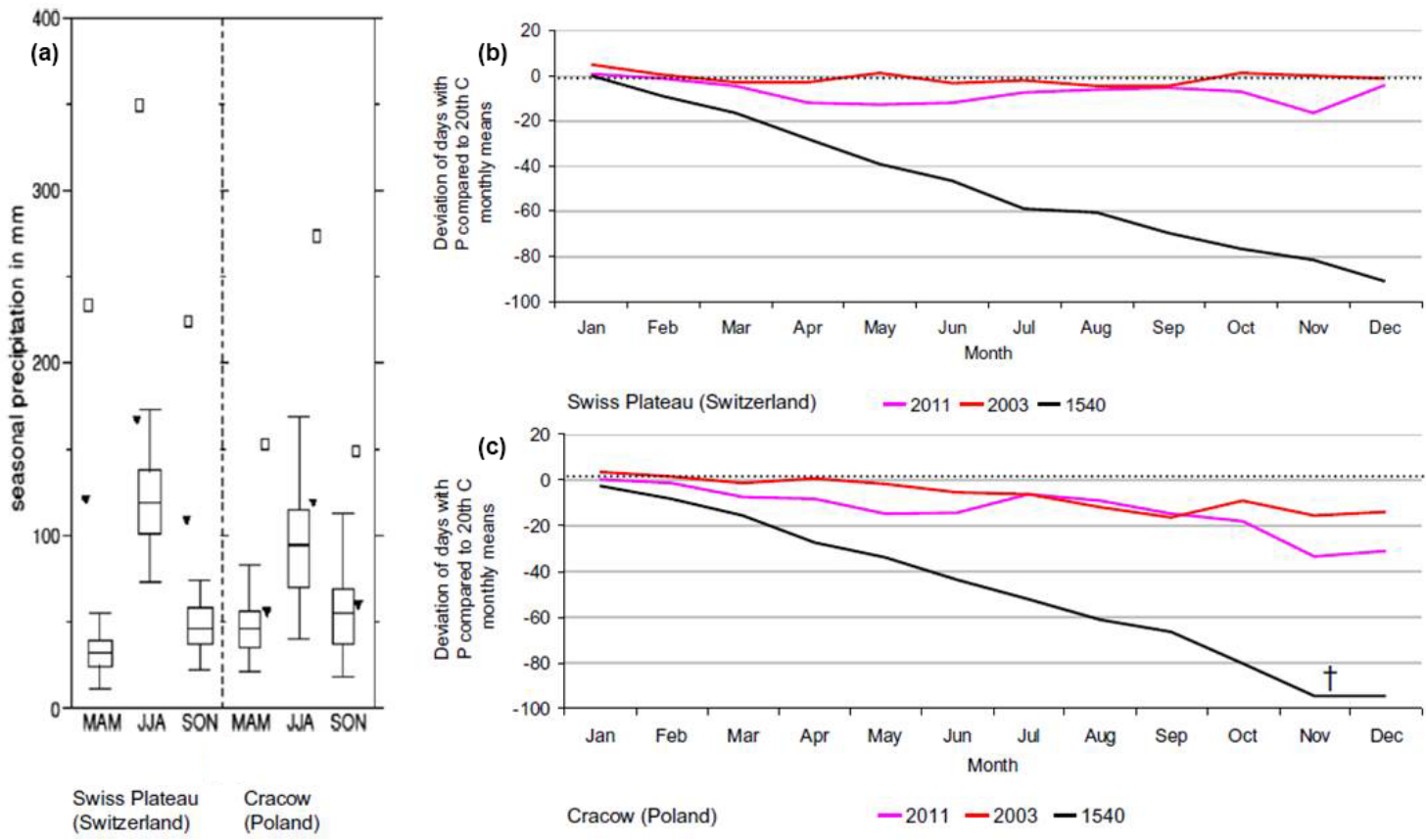

Figure 15. Reconstructed seasonal precipitation amounts for spring, summer and autumn and cumulative deviations of 1540 NPD compared to the 20th century mean, 2011 and 2003. (a) Median, upper and lower quartiles (boxes), $95 \%$ uncertainties (whiskers) as well as 50- and 100-year minimum levels (box and triangle) of 20th century data for the Swiss Plateau (northern Switzerland) average (a) and Cracow (b). (b) compares cumulative deviations of NPD in northern Switzerland in 2011, 2003 and 1540. NPD for 2003 and 2011 is taken from the Federal Office of Meteorology and Climatology, MeteoSwiss (NPD was averaged over the stations of Basel, Lucerne, Schaffhausen and Zürich). Dotted line: 20th century mean of days with precipitation $\geq 1 \mathrm{~mm}$. (c) compares cumulative deviations of NPD in Cracow, Poland, in 2011, 2003 and 1540. NPD for 2003 and 2011 is taken from the Center for Poland's Climate Monitoring. Dotted line: 20th century mean of days with precipitation $\geq 1 \mathrm{~mm}$; $\dagger$ date of death of Marcin Biem: 19 November 1540 (Wetter et al., 2014). 


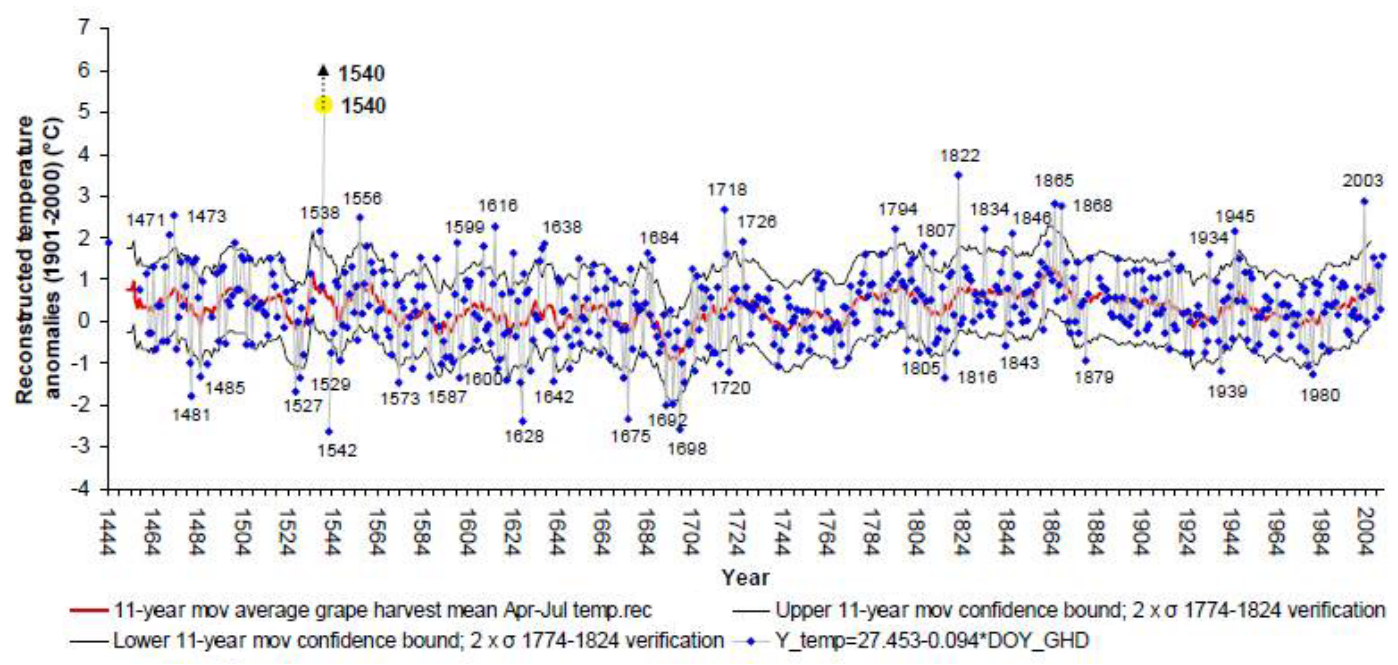

Figure 16. Temperature anomalies compared to the 20th century based on grape harvest dates' linear regression calculations (Wetter and Pfister, 2013).

umented where all three seasons successively underbid the 100-year PA minima as well as the absolute minima of the NPD within the instrumental period in Switzerland. This finally caused the record-breaking low water level of the Rhine River in Basel and other sites in Switzerland and Europe.

The extreme dryness throughout 1540 across central Europe led to an extraordinary soil-moisture and evapotranspiration deficit, which was described by numerous chroniclers with reference to extreme soil cracking, the failure of wells, fruitless digging for groundwater in dried-out river beds, and leaf fall of trees and vines due to heat stress. In temperate climates, a considerable part of incoming shortwave radiation is generally used for evapotranspiration (i.e. humidification of water from vegetation, soils and water surface sources), which is called the latent heat flux. The remaining sensible heat flux ultimately impacts air temperature. In the case of a strong soil-moisture deficit the share of sensible heat increases as the latent heat flux gets weaker due to decreasing moisture sources, which consequently leads to increased air temperatures. Increased air temperature on the other hand leads to a higher evaporative demand and thus to a potential increase in evapotranspiration, leading to a further decrease in soil moisture until the total drying of the soil when temperature increases cannot be dampened by further increases in evapotranspiration anymore (Seneviratne et al., 2010). In these cases rapid and extreme increases in temperatures are observed. Spring-summer temperatures were assessed by calibrating grape harvest dates (GHD) with the monthly anomalies from 1901 to 2000 mean of HISTALP temperature series, which resulted in a linear regression equation where GHD served as temperature proxies (Wetter and Pfister, 2013). GHD for 1540 is not available, which is why it had to be deduced from full maturity of grapes and the temporal difference between veraison and the usual beginning of the grape harvest. Based on the veraison date and the full ripeness of the grape (both are known for 1540), GHD was assessed between 12 and 25 August, marking the margins of fluctuation within full grape maturity, when under normal circumstances grape harvest would have occurred (Wetter and Pfister, 2013). The temperature anomaly for May-July temperatures thus assessed amounted to +4.7 and $+6.8^{\circ} \mathrm{C} \mathrm{com-}$ pared to the 20th century mean (Fig. 16).

In case no (agro-)phenological data (like GHDs) are available, it is still possible to use weather descriptions, which may refer to considerable phenological anomalies (e.g. blossoming of trees in winter), reference the cryosphere (e.g. the description of freezing over of lakes and rivers) or provide general descriptions of temperature and precipitation (e.g. remarks about mild winter temperatures or wet summer conditions) to assess the weather-related contexts of preinstrumental flood or drought events. Pfister (1999) developed a seven-step index $(-3 /-2 /-1 / 0 /+1 /+2 /+3)$ to quantify such qualitative narrative information and was able to reconstruct a monthly resolved temperature and precipitation series for the period 1496-1995. The following section will demonstrate the very high potential of municipal accounts to significantly improve the already existing precipitation reconstruction in Switzerland (Pfister, 1999).

\subsection{Reconstruction of the long-term seasonality of minor pre-instrumental flood events based on institutional sources}

The books of weekly expenditures of the city of Basel include records concerning wage payments for craftsmen and guards who were engaged to protect the Rhine bridge and the inlet fence of the Birsig River at the city gates from possible destruction due to floating debris. Recently the pe- 


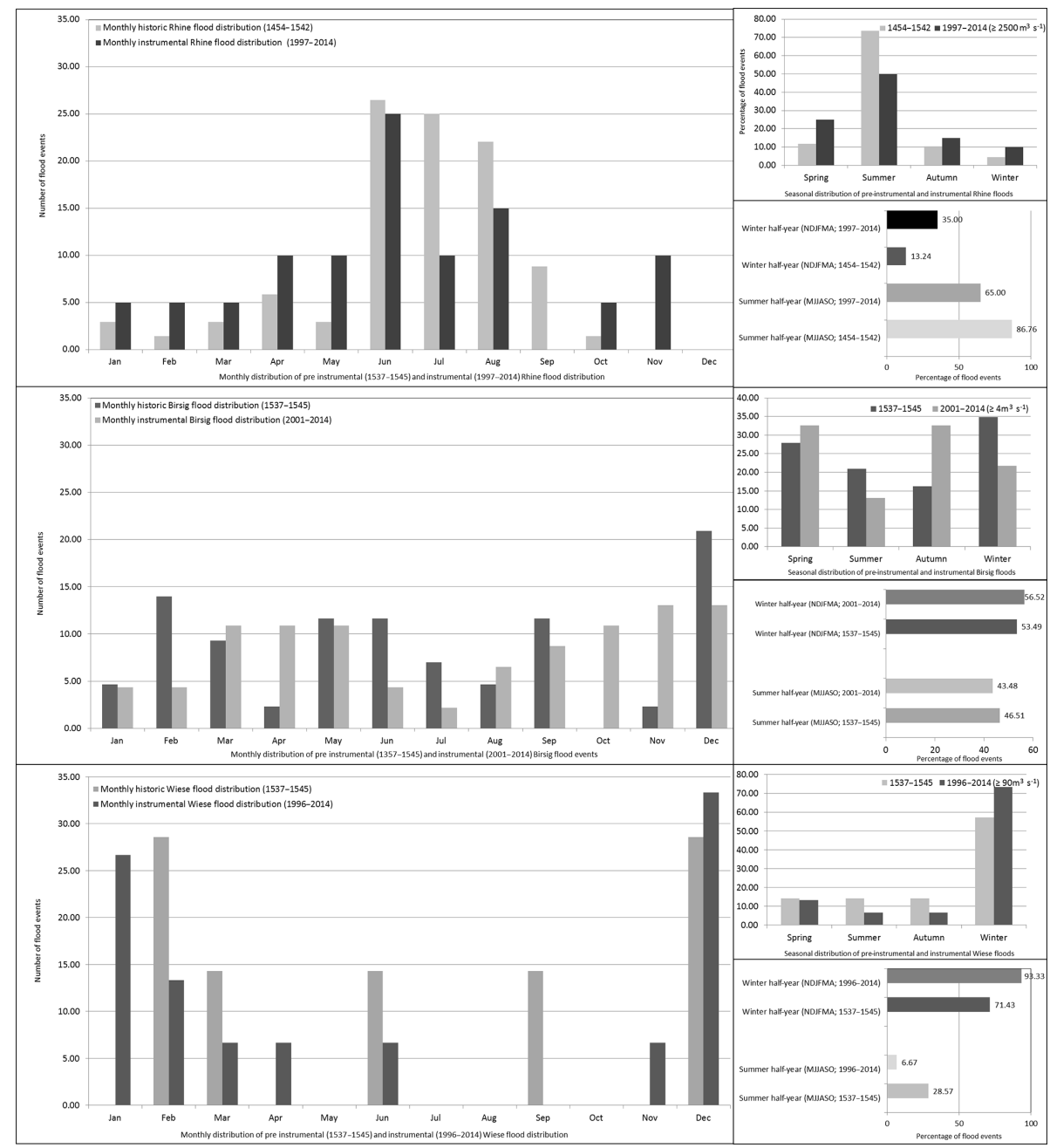

Figure 17. Distribution of historical and instrumental Rhine, Birsig and Wiese flood events in comparison.

riod from 1600 to 1650 was completely analysed (Spycher, 2017), and 70 Rhine and 218 Birsig River flood events were detected, whereas chroniclers in the same period only reported on 3 Rhine and 5 Birsig floods. This ratio of $23: 1$ for Rhine floods and 44:1 for Birsig floods clearly demonstrates the significantly sharper "observation skills" of the city accounts for minor and much more frequent flood events (flood return period $\leq 1$ year). The quality and reliability of these historic records were checked by comparing whether the monthly, seasonal and half-yearly distributions of the historic flood events resemble the distribution during the instrumental period. As the historic records in the municipal accounts do not provide information about the minimum discharge amount that was needed to cause preventive protection measures, which would define the "flood" events in the instrumental period, the flood definition was specified as follows: under the assumption that both series (historic and instrumental) were comparable, a simple ratio of the length of the historic series to the length of the instrumental Rhine and Birsig series was calculated. This ratio defined the number of events that had to be considered in the instrumental period, which at the same time also defined the minimum discharge that probably was needed to cause preventive protection measures in historic times. Figure 17 shows overall good visible correlations of the monthly and seasonal distributions of flood events between the historic and instrumental Rhine, Birsig and Wiese flood events, enhancing our confidence that the indirect flood information from the municipal accounts is a valid flood proxy. A closer examination of the analysed 50-year period from 1600 to 1650 reveals that our assumption about the good quality and reliability of this flood proxy seems to have been correct. Figure 18 demonstrates the monthly distribution of Rhine and Birsig brook flood events in the historic and instrumental periods. The overall correlation amounted to 0.81 for the River Rhine and 0.47 for the Birsig brook (Pearson).

The latter, relatively weak, correlation can be explained by the fact that the instrumental period of Birsig brook is rather 

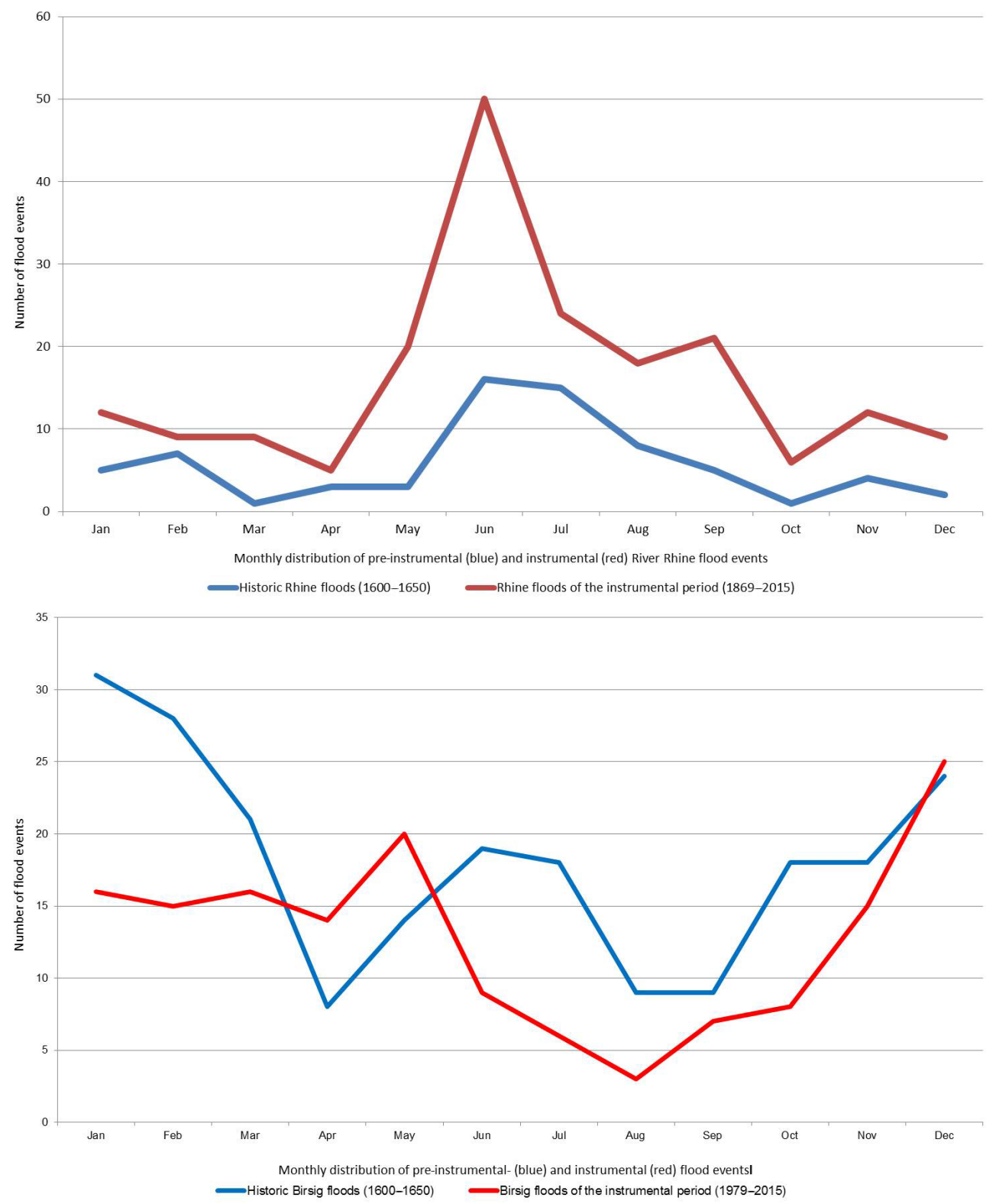

Figure 18. Distribution of historical and instrumental Rhine and Birsig flood events in comparison.

short and the measurement station is several kilometres upstream of the historic flood information (above the inflow of some tributaries). Further analysis is required once all flood proxies from the weekly books of expenditures have been extracted (1401-1799) to ascertain whether the significant accumulation of historical Birsig "floods" in January and February might have been triggered by a climatic anomaly (LIA?) or whether the winter months (DJF) might in fact contain mixed information about floods on the one hand and ice on the other hand. An icebound river can in fact be a potential threat to the infrastructure and may cause severe flooding, which might have justified the extra watches. The second explanation (mixed signals) is probably the more plau- sible one. All other months (MAMJJASOND) are more or less in agreement with the instrumental measurement period, which implies that they might represent undisturbed flood proxies (see Figs. 17 and 18). Figures 19 and 20 demonstrate that several Rhine River and Birsig brook flood events, e.g. in 1640 (12 Birsig and 10 Rhine flood event records), cannot be explained by preceding and actual reconstructed temperature (Dobrovolný et al., 2009) and precipitation (Pfister, 1999) reconstructions, which suggests that the precipitation reconstruction especially is not yet as good as it could be. This is not unexpected as currently available precipitation reconstructions are predominantly based on direct descriptions of wet or dry conditions or on reported flood events 

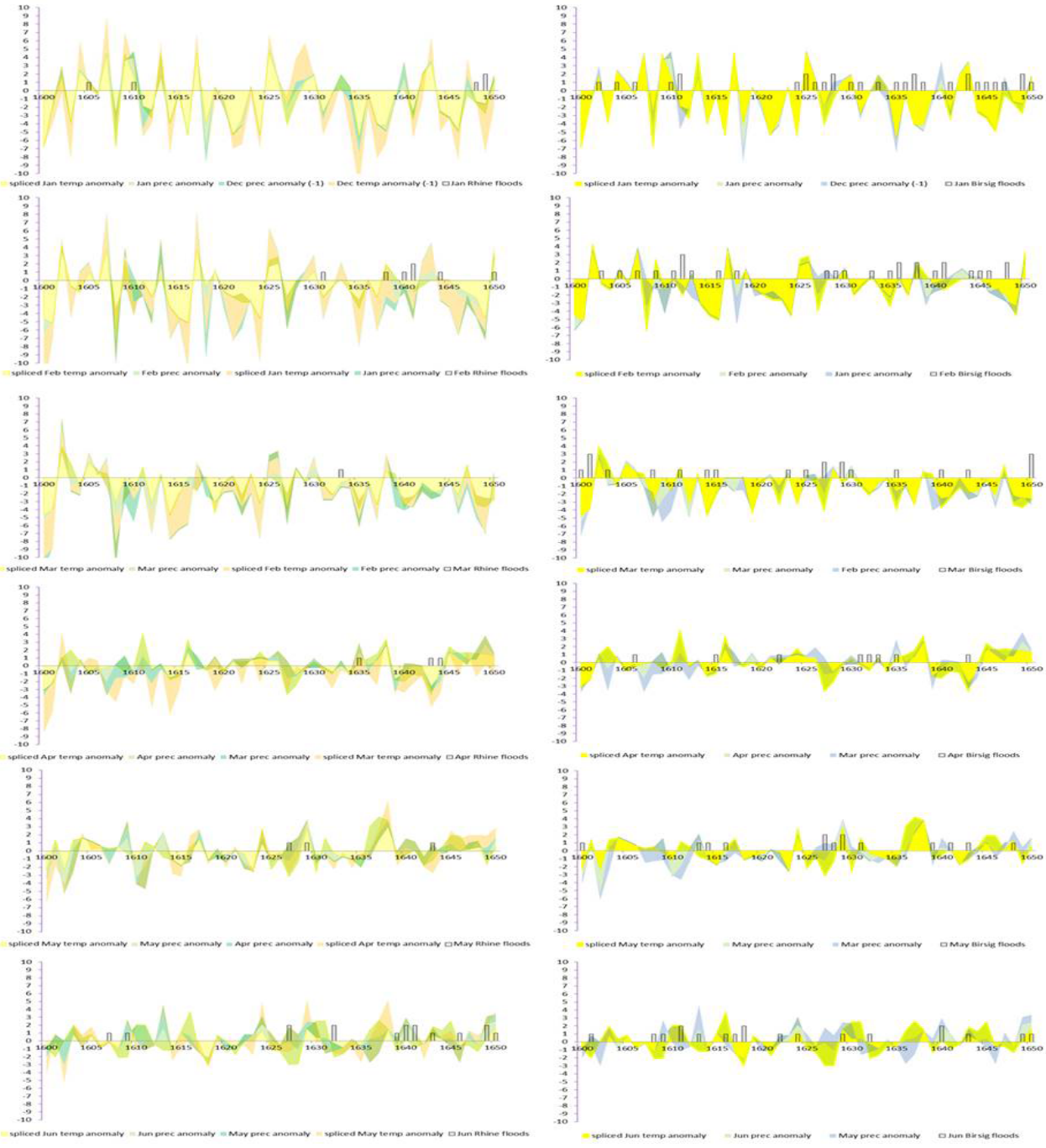

Figure 19. Monthly spliced temperature (Dobrovolný et al., 2009) and precipitation (Pfister, 1999) reconstructions combined with Rhine and Birsig River flood proxies from the weekly books of expenditures from the city of Basel - January to June.

by chroniclers. The problem is that chroniclers tend to describe extreme events only, be it floods, temperature or precipitation, so that information about normal events is usually underrepresented. The flood proxies extracted from institutional sources, like the weekly books of expenditures of the city of Basel, do have a much "lower observation threshold" and therefore also include normal events, which makes them highly valid for use in significantly improving existing precipitation reconstructions. The fact that the city accounts simultaneously record intensified flood occurrence for both "catchments", the local (Birsig) and the supra-regional (Rhine), beginning in June 1640, supports their mutual credibility. The simultaneousness of the intensified flood records in the two catchments makes it implausible that the intensified Rhine bridge and Birsig fence watches were carried out for other reasons, e.g. repair works.

\section{Conclusion and outlook}

It has been demonstrated that the historical documentary evidence situation, allowing us to reconstruct and assess climatic parameters (e.g. temperature or precipitation) as well as hydrological events, is remarkably strong in Switzerland. A number of factors have led to good record preservation, including the near absence of direct involvement of Swiss cities in major destructive war activities, the absence of cumulative natural disasters and the existence of effective municipal measures against non-cumulative disasters, as well as the more recent economic wealth and its positive aspects in the support of countless state and local municipal archives. Existing historical documentary evidence as well as basic methodologies to reconstruct the long-term frequency, seasonality and magnitudes of pre-instrumental hydrological events have been introduced and their strengths and weak- 

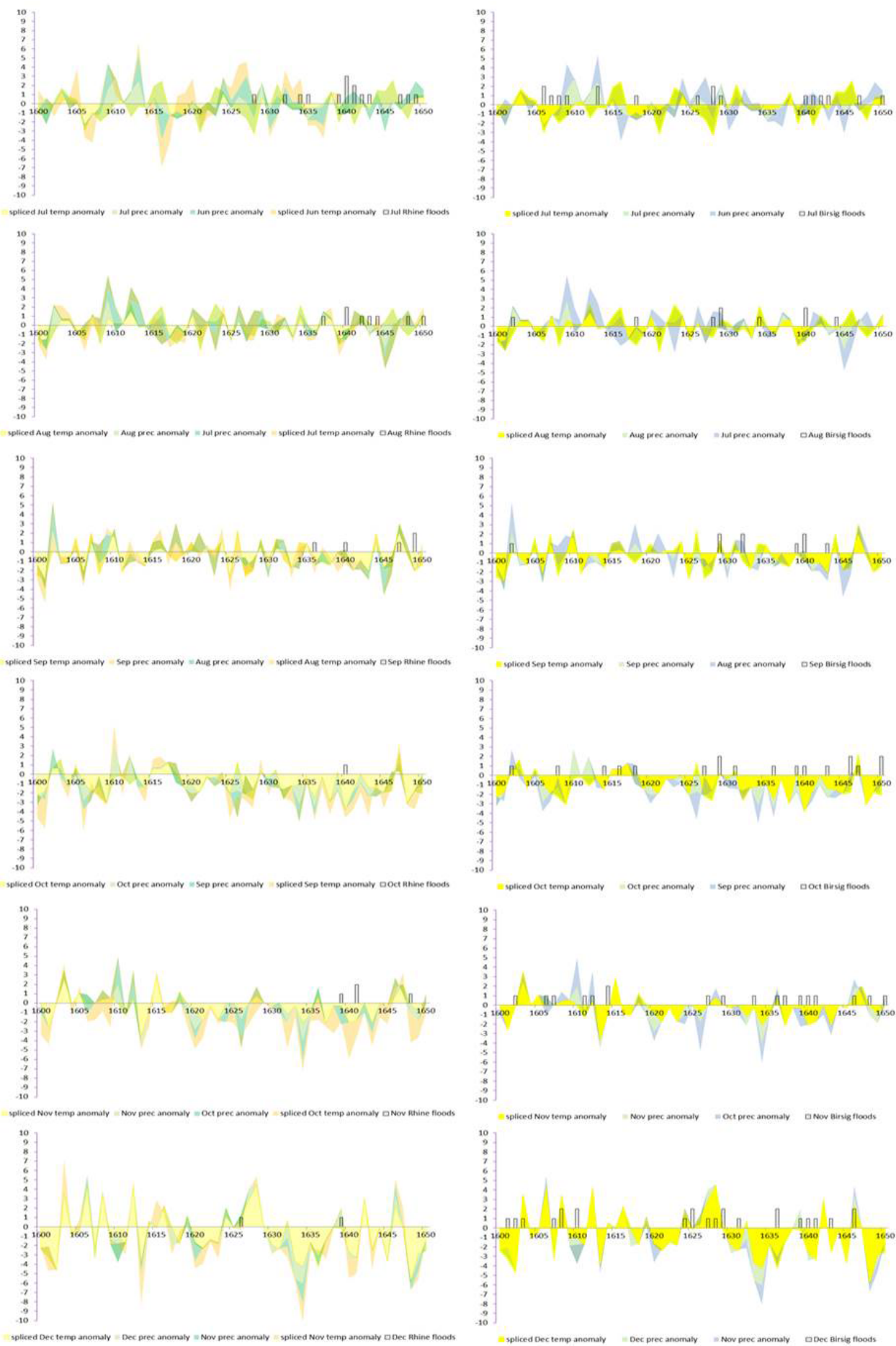

Figure 20. Monthly spliced temperature (Dobrovolný et al., 2009) and precipitation (Pfister, 1999) reconstructions combined with Rhine and Birsig River flood proxies from the weekly books of expenditures from the city of Basel - July to December.

nesses have been briefly discussed. Prospects are good that reconstructed pre-instrumental flood magnitudes (in water level or discharge) may be homogenised to actual runoff conditions, so that floods of pre-anthropogenic river engineering measures may be compared to the more recent floods under the actual anthropogenically influenced runoff conditions (paper in preparation). Furthermore it has been shown that the analysis of the books of weekly expenditures of the city of Basel provides significantly improved "observation skills" in small and normal flood events which are usually not 


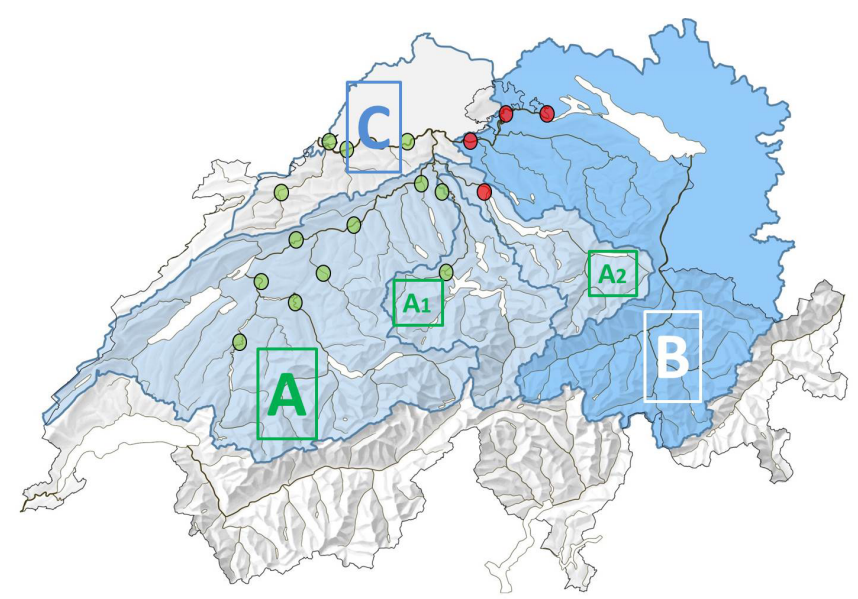

Figure 21. Contribution (green dots) and non-contribution (red dots) of rivers to particular pre-instrumental minor flood events. A: Aare catchment; A1: Reuss catchment; A2: Limmat catchment; B: High Rhine catchment; C: Jura catchment.

recorded by chroniclers or journalists. In the fully analysed 50-year period between 1600 and 1650, the ratio between flood evidence from chroniclers and municipal accounting records amounts to $1: 23$ in the case of the Rhine and $1: 44$ in the case of Birsig brook flood events. Preliminary investigation revealed that analogous institutional sources like the books of weekly expenditures of the city of Basel do exist in almost every other Swiss town. These records usually start in the 14th, 15th or 16th centuries. They are mostly labelled as "Säckelmeisterrechnungen", which is the late Medieval term for the chief officer of the cash receipts, or simply as "Stadtrechnungen" (city accounts). Even though many of these municipal account books are on a 6-monthly level only, making dating of flood events less accurate, we have good reasons to assume that their observation skills in small and normal flood events are comparable to those in Basel, because bridges and fences were basically subject to the same threats, and the system of guarding and protecting them was principally the same. The reconstruction of longterm seasonality and the frequency of small and normal preinstrumental flood events should therefore be possible for countless rivers and brooks at different sites in Switzerland. A complete analysis would expand the experience base about small and normal flood events, which so far is strictly limited to the instrumental period, for several centuries into the pre-instrumental past, as, unlike for extreme flood events, no historical hydrological reconstructions are available yet in Switzerland. Reconstructions like this, once analysis has been expanded to other neuralgic sites, would furthermore significantly deepen our understanding of the genesis of particular flood events, and drawing of some principal conclusions about meteorological triggers - by analysing the contribution and non-contribution of rivers - would be possible.
If, for example, the municipal accounts from Fribourg, Bern, Aarberg, Delémont, Solothurn, Burgdorf, Olten, Lucerne, Laufenburg, Rheinfelden and Basel contained flood records (green dots in Fig. 21) while accounts from eastern Switzerland (red dots in Fig. 21) remained silent, the conclusion could safely have been drawn that this specific flood event was primarily triggered by the catchments of the Aare River and its tributaries (namely by the rivers Saane, Emme, Birs and Reuss), whereas the catchment of the High Rhine, upstream of the confluence of the Aare, did not play a major role. The meteorological trigger of this hypothetical flood event, according to the distribution of the contributing and non-contributing rivers, therefore quite clearly points to a western-based origin of the flood wave. The books of weekly expenditures also contain records about hay and after-grass harvests. Spycher (2017) compared these harvest dates with monthly resolved precipitation and temperature anomalies (Pfister, 1998) and found significant correlations between early and late onsets of hay and after-grass harvest dates and the preceding months with dry or moist weather anomalies. These hay and after-grass harvest data series are thus of great value for further historical climatological analysis. They improve and (chronologically) expand the already existing temperature and precipitation series back in time and furthermore may help to shed light on weather conditions in advance and during pre-instrumental flood events. It seems, as indicated in the abstract, that non-scientific peer group interest in historical hydrological analysis, especially from the public ministries and local offices responsible, has significantly increased in the last few years in Switzerland. If this interest lasts, it would initialise a huge potential for further historical hydrological analysis partly in cooperation with private engineering companies and would help to significantly improve flood risk analysis from which the public sector would certainly benefit as well. Further historical hydrological research, especially based on municipal accounting records, is needed and required as it promises highly valuable results of as yet unreached quality.

Data availability. The easiest access to specific data would be to contact the main author by mail: oliver.wetter@hist.unibe.ch.

Competing interests. The authors declare that they have no conflict of interest.

Special issue statement. This article is part of the special issue "Floods and their changes in historical times - a European perspective". It is not connected with a conference.

Acknowledgements. I would like to thank Fiona Spycher, Beat von Scarpatetti and Daniel Tuttenuj for transcribing the books 
of weekly expenditures of the city of Basel. Thanks furthermore go to the Swiss National Science Foundation (SNSF) for support. This paper is related to SNSF project 153327 "Reconstruction of the genesis, process and impact of major pre-instrumental flood events of major Swiss rivers including a peak discharge quantification".

Edited by: Andrea Kiss

Reviewed by: Inês Amorim, Silvia Enzi, and

one anonymous referee

\section{References}

Arnold, K.: Der wissenschaftliche Umgang mit Quellen, in: Geschichte, Ein Grundkurs, edited by: Goertz, H.-J., 2. Auflage, Hamburg, 42-58, 2001.

Basler Chroniken: Die Aufzeichnungen des Adelberg Meyers 3741542, 6. Band, 1902.

Boerlin-Brodbeck, Y. and Büchel, E.: SIKART Lexikon zur Kunst in der Schweiz, available at: http://www.sikart.ch/ KuenstlerInnen.aspx ?id=4024279 (last access: 22 November 2017), 2006.

Bolzern, M.: Reconstruction of historical floods of the Aare River in Aarau, in: Berner Studien zur Geschichte, in preparation, 2018.

Brázdil, R., Pfister, C., Wanner, H., von Storch, H., and Luterbacher, J.: Historical Climatology in Europe - State of the Art, Climatic Change, 70, 363-430, 2005.

Brázdil, R., Kundzewicz, Z. W., and Benito, G.: Historical hydrology for studying flood risk in Europe, Hydrolog. Sci. J., 51, 739764, 2006.

Christian, S.: Die Helvetik als Revolution in Staat, Wirtschaft und Gesellschaft, 1798/1998, in: Die Helvetik und ihre Folgen, edited by: Tobler, H. W., Zürich, 49-72, 1998.

Chow, V. T.: Open Chanel Hydraulics, New York, McGraw-Hill, 1973.

D'Aujourd'hui, R. and Lavicka, P.: Zusammenfassende Bemerkungen zu den Sondierungen in der mittelalterlichen Talstadt, in: Basler Zeitschrift für Geschichte und Altertumskunde, Band 82, Basel, 1982.

Dobrovolný, P., Moberg, A., Brázdil, R., Pfister, C., Glaser, R., Wilson, R., van Engelen, A., Limanówka, D., Kiss, A., Halíčkova, M., Macková, J., Riemann, D., Luterbacher, J., and Böhm, R.: Monthly, seasonal and annual temperature reconstructions for Central Europe derived from documentary evidence and instrumental records since AD 1500, Climatic Change, 101, 69-107, 2009.

Fouquet, G.: Der Zimmerer- und Brückenwerkmeister, in: Bauen für die Stadt, Finanzen, Organisation und Arbeit in kommunalen Baubetrieben des Spätmittelalters, Eine vergleichende Studie vornehmlich zwischen den Städten Basel und Marburg (Städteforschung: Reihe A, Darstellungen; Bd. 48), Köln, Weimar, Wien, Böhlau, 210-225, 1999.

Glaser, R., Riemann, D., Schönbein, J., Barriendos, M., Brázdil, R., Bertolin, C., Camuffo, D., Deutsch, M., Dobrovolný, P., van Engelen, A., Enzi, S., Halícková, M., König, S. J., Kotyza, O., Limanowka, D., Macková, J., Sghedoni, M., Martin, B., and Himmelsbach, I.: The variability of European floods since AD 1500, Climatic Change, 101, 235-256, 2010.
Heim, R. R.: A review of twentieth-century drought indices used in the United States, B. Am. Meteorol. Soc., 83, 1149-1165, 2002.

Hirzel, S.: Anonyme Zusätze und Fortsetzungen zu Königshofen, nach der Abschrift Erhards von Appenwiler 1120-1454, in: Basler Chroniken, edited by: Historischen und Antiquarischen Gesellschaft in Basel, Band 4, Leipzig, 522 pp., 1890.

Hirzel, S.: Die Aufzeichnungen des Kaplans Hieronymus Brilinger, 1474-1525, in: Basler Chroniken, edited by: Historischen und Antiquarischen Gesellschaft in Basel), Band 7, Leipzig, 528 pp., 1915.

Küng, F.: Luzern, Bauen am Fluss, Archäologische Untersuchungen an der Kronengasse 6-10, Archäologische Schriften Luzern, 569, 2006.

Kjeldsen, T. R., Macdonald, N., Lang, M., Mediero, L., Albuquerque, T., Bogdanowicz, E., Brázdil, R., Castellarin, A., David, V., Fleig, A., Gül, G. O., Kriauciuniene, J., Kohnová, S., Merz, B., Nicholson, O., Roald, L. A., Salinas, J. L., Sarauskiene, D., Sraj, M., Strupczewski, W., Szolgay, J., Toumazis, A., Vanneuville, W., Veijalainen, N., and Wilson, D.: Documentary evidence of past floods and their utility in flood frequency estimation, J. Hydrol., 517, 963-973, 2014.

Lanz-Stauffer, H. and Rommel, C.: Rückversicherungsverband kantonal-schweizerischer feuerversicherungsanstalt, Bern, 1936.

Lehmann, C. S.: Spätmittelalterlicher Nationalismus: die Burgunderkriege am Oberrhein und in der Eidgenossenschaft, Veröffentlichungen des Max-Planck-Instituts für Geschichte, 116, Vandenhoeck \& Ruprecht, Göttingen, 488 pp., 1995.

Longoni, R.: Saanehochwasser und kommunaler Hochwasserschutz in Freiburg i. Ü., 1387-1570, in: Freiburger Geschichtsblätter 74, 45 pp., 2017.

Longoni, R. and Wetter, O.: Urban River Works in Central Europe 1200-1700, State of the Art, Sources and Potentials, Water History, in preparation, 2017.

Luterbacher, J. and Pfister, C.: The year without a summer, Nat. Geosci., 8, 246-248, 2015.

Meyer, W.: Da verfiele Basel überall, Das Basler Erdbeben von 1356, Mit einem geologischen Beitrag von Hans Peter Laubscher, Schwabe, Basel, 230 pp., 2006.

Mudelsee, M., Börngen, M., Tetzlaff, G., and Grünewald, U.: Extreme floods in central Europe over the past 500 years: Role of cyclone pathway "Zugstrasse Vb", J. Geophys. Res., 109, D23101, https://doi.org/10.1029/2004JD005034, 2004.

Näf-Huber, D., Scherrer, S., Wetter, O., Specker, T., Oplatka, M., and Eisenhut, N.: Hochwasserschutz Zürich - Seestände und Abfluss, Heute mit dem Schiff ins Zürcher Fraumünster?! Wasser Energie Luft, 108, Jahrgang, Heft 2, Baden, 2016.

Nast, M.: überflutet - überlebt - überlistet, Die Geschichte der Juragewässerkorrektionen, Verein Schlossmuseum Nidau, 192 pp., 2006.

Paravacini, G.: Gestautes Wasser - Regulierter See, Geschichte, Bau und Betrieb der Reusswehranlage in Luzern, Kantonaler Lehrmittelvertrag Luzern, 191 pp., 2013.

Pfister, C.: Raum-zeitliche Rekonstruktion von Witterungsanomalien und Naturkatastrophen 1496-1995, (unter Mitarbeit von Daniel Brändli, Schlussbericht zum Projekt 4031-33198 des NFP 31) Hochschulverlag ETH, Zürich, 1998.

Pfister, C.: Wetternachhersage, 500 Jahre Klimavariationen und Naturkatastrophen (1496-1995), Verlag Paul Haupt, Bern, Stuttgart, Wien, 304 pp., 1999. 
Pfister, C.: Die Katastrophenlücke des 20. Jahrhunderts und der Verlust traditionalen Risikobewusstseins, in: GAIA Ecological Perspectives for Science and Society, 3, 239-246, 2009.

Pfister, C.: The Monster Swallows You, Disaster Memory and Risk Culture in Western Europe, 1500-2000, Rachel Carson Center Perspectives 1/2011, 1-23, 2011.

Pfister, C. and Wetter, O.: Das Jahrtausendhochwasser von 1480 an Aare und Rhein, Berner Zeitschrift für Geschichte, 74, 41-49, 2011.

Pfister, C., Weingarnter, R., and Luterbacher, J.: Hydrological winter droughts over the last 450 years in the Upper Rhine basin: a methodological approach, Hydrolog. Sci. J., 51, 966-985, 2006.

Pfister, C., Luterbacher, J., Wanner, H., Wheeler, D., Brázdil, R., Ge, Q., Hao, Z., Moberg, A., Grab, S., and Rosario Del, P. M.: Documentary evidence as Climate Proxies. Proxy-specific White Paper produced from the PAGES/CLIVAR workshop, Trieste, 2009.

Przegon, W.: Jan Pawel Lelewels Generalplan zum Projekt der Trockenlegung der Sumpfgebiete des Seelandes (1834), in: Vermessung Photogrammetrie Kulturtechnik Heft 8, 432-434, 1999.

Remark, J.: Bruderzwist, nicht Brudermord, Der Schweizer Sonderbundkrieg von 1847, Orell Füssli, Zürich, 285 pp., 1997.

Röthlisberger, G.: Chronik der Unwetterschäden in der Schweiz, Berichte der Eidgenössischen Forschungsanstalt für Wald, Schnee und Landschaft, 330, 123 pp., Birmensdorf, 1991.

Salvisberg, M.: Der Hochwasserschutz an der Gürbe, Eine Herausforderung für Generationen (1855-2010) (Wirtschaft-, Sozialund Umweltgeschichte (WSU) 7), 406 pp., Basel, 2017.

Schmocker-Fackel, P. and Naef, F.: Changes in flood frequencies in Switzerland since 1500, Hydrol. Earth Syst. Sci., 14, 1581-1594, https://doi.org/10.5194/hess-14-1581-2010, 2010.

Seneviratne, S. I., Corti, T., Davin, E. L., Hirschi, M., Jaeger, E. B., Lehner, I., Orlowsky, B., and Teuling, A. J.: Investigating soil moisture-climate interactions in a changing climate: A review, Earth Sci. Rev., 99, 125-161, 2010.

Seneviratne, S. I., Nicholls, D., Easterling, C. M., Goodess, S., Kanae, J., Kossin, Y., Luo, J., Marengo, K., McInnes, M., Rahimi, M., Reichstein, A., Sorteberg, V. C., and Zhang, X.: Changes in climate extremes and their impacts on the natural physical environment, in: Managing the Risks of Extreme Events and Disasters to Advance Climate Change Adaptation, edited by: Field, C. B., Barros, V., Stocker, T. F., Qin, D., Dokken, D. J., Ebi, K. L., Mastrandrea, M. D., Mach, K. J., Plattner, G. K., Allen, S. K., Tignor, M., and Midgley, P. M., A Special Report ofWorking Groups I and II of the Intergovernmental Panel on Climate Change, 109-230, 2012.

Sheffield, J., Wood, E. F., and Roderick, M. L.: Little Change in global drought over the past 60 years, Nature, 49, 435-438, https://doi.org/10.1038/nature11575, 2012.
Spycher, F.: Witterungsbedingte Ausgaben des Basler Rates. Eine Untersuchung der Basler- Wochenausgabenbücher 1600-1650., MA-Thesis, Historisches Institut, Abteilung für Wirtschaft-, Sozial- und Umweltgeschichte (WSU), Universität Bern, 131 pp., 2017.

Stedinger, J. R. and Griffis, V. W.: Getting from here to where? Flood frequency analysis and climate, JAWRA J. Am. Water Resour. Assoc., 47, 506-513, 2011.

Sturm, K., Glaser, R., Jacobeit, J., Deutsch, M., Brázdil, R., Pfister, C., Luterbacher, J., and Wanner, H.: Hochwasser in Mitteleuropa seit 1500 und ihre Beziehung zur atmosphärischen Zirkulation, Petermanns Geographische Mitteilungen, 145, 14-23, 2001.

Vischer, D.: Die Geschichte des Hochwasserschutzes in der Schweiz, Von den Anfängen bis ins 19. Jahrhundert, Berichte des BWG, Serie Wasser, 5, 3-208, 2003.

Wetter, O.: Hochwasser "Katastrophen" in Basel vom 13. bis 21. Jahrhundert: Rekonstruktion, Deutung und Lerneffekte, in: Krisen - Crises, Ursachen, Deutungen, Folgen, Schweizerisches Jahrbuch für Wirtschafts- und Sozialgeschichte, edited by: David, T., Mathieu, J., Schaufelbuehl, J. M., and Straumann, T., Chronos Verlag, Zürich, 27, 48-63, 2012.

Wetter, O. and Pfister, C.: An underestimated record breaking event - why summer 1540 was likely warmer than 2003, Clim. Past, 9, 41-56, https://doi.org/10.5194/cp-9-41-2013, 2013.

Wetter, O. and Specker, T.: HWS Sihl-Limmat, Schlussbericht Historische Studien. Nicht öffentlicher Untersuchungsbericht zuhanden des Amtes für Wasser, Energie und Luft des Kantons Zürich (AWEL), 66 pp., 2015.

Wetter, O., Pfister, C., Weingartner, J., Luterbacher, J., Reist, T., and Trösch, J.: The largest floods in the High Rhine basin since 1268 assessed from documentary and instrumental evidence, Hydrolog. Sci. J., 56, 733-758, 2011.

Wetter, O., Pfister, C., Werner, J.P., Zorita, E., Wagner, S., Seneviratne, I. S., Herget, J., Grünewald, U., Luterbacher, J., Alcoforado, M.-J., Barriendos, M., Bieber, U., Brázdil, R., Burmeister, K. H., Camenisch, C., Contino, A., Dobrovolný, P., Glaser, R., Himmelsbach, I., Kiss, A., Kotyza, O., Labbé, T., Limanovká, D., Litzenburger, L., Nordli, Ø., Pribyl, K., Retsö, D., Riemann, D., Rohr, C., Siegfried, W., Söderberg, W., and Spring, J.-L.: The year-long unprecedented European heat and drought of 1540 - a worst case, Climatic Change, 125, 365-367, 2014.

Wetter, O., Tuttenuj, D., and Longoni, R.: Rekonstruktion vorinstrumenteller Scheitelwasserstände der Aare - einschliesslich ihrer wichtigsten Zubringer Saane, Emme, Reuss und Limmat inklusive einer Meteoumfeldanalyse für die extremsten Hochwasser, Nicht öffentlicher Untersuchungsbericht zuhanden des Bundesamt für Umwelt (BAFU), 128 pp., 2015. 